Fall 2003

\title{
"On the Chastity of Women All Property in the World Depends" : Injury from Sexual Slander in the Nineteenth Century
}

Lisa R. Pruitt

University of California, Davis School of Law

Follow this and additional works at: https://www.repository.law.indiana.edu/ilj

Part of the Law and Gender Commons, Legal History Commons, and the Sexuality and the Law Commons

\section{Recommended Citation}

Pruitt, Lisa R. (2003) "'On the Chastity of Women All Property in the World Depends" : Injury from Sexual Slander in the Nineteenth Century," Indiana Law Journal: Vol. 78 : Iss. 3 , Article 2.

Available at: https://www.repository.law.indiana.edu/ilj/vol78/iss3/2

This Article is brought to you for free and open access by the Law School Journals at Digital Repository @ Maurer Law. It has been accepted for inclusion in Indiana Law Journal by an authorized editor of Digital Repository @ Maurer Law. For more information, please contact rvaughan@indiana.edu.

\section{$\Psi$}

JEROME HALL LAW LIBRARY

INDIANA UNIVERSITY

Maurer School of Law
Blooming ton 


\title{
"On the Chastity of Women All Property in the World Depends"': Injury from Sexual Slander in the Nineteenth Century ${ }^{\dagger \dagger}$
}

\author{
LISA R. PRUITT*
}

In this Article, Professor Pruitt discusses conceptions of the injury associated with defamation law, focusing in particular on sexual slander cases that were brought in the early nineteenth century, before statements that impugned a woman's chastity were deemed slander per se. During this time, women had to prove so-called "special damages" in order to state a cause of action. Courts showed some flexibility in what they recognized as constituting "special damages," even stretching to recognize pecuniary harm in damaged personal relationships. Nevertheless, courts refused to recognize injuries stemming from and related to emotional distress injuries, and they were often skeptical that a variety of harms claimed by women were the direct and natural consequences of the offending statement.

In studying what courts viewed to be special damages and therefore worthy of redress in this context, Professor Pruitt's work reveals several insights. First, we learn something of the nature of the reputational interest protected by defamation law. In particular, Professor Pruitt argues that courts viewed these slandered women's reputations as a form of property, and they ignored the dignitary nature of the injury. In addition, these cases provide an opportunity to see another example of the gendered trends in tort law that have been identified by scholars such as Professor Martha Chamallas. Professor Chamallas has argued that tort law values property and economic injury over relational and emotional injury, and that injuries may be judicially characterized as one or the other based upon the gender of the sufferer. Professor Pruitt's analysis points out the presence of these value hierarchies in sexual slander cases, just as Professor Chamallas has established their presence elsewhere in tort law.

† Anne McClintock, Sex Workers and Sex Work, Introduction, 37 Soc. TEXT 1 (1993) (referring to Samuel Johnson's "famous quote"). See infra note 243.

${ }^{\dagger \dagger}$ Copyright 2003 Lisa R. Pruitt.

* Acting Professor, University of California, Davis School of Law, Martin Luther King, Jr. Hall. Thanks to participants in the Subversive Legacies Conference, University of Texas, November 2002, for thoughtful comments. David Herbert provided editorial assistance. Several research assistants read numerous defamation cases in the furtherance of this and related projects, and I gratefully acknowledge all for their excellent work: Kelly Z. Bowra, Jennifer D. Haffner, Cary Huxsoll, Rebecca B. Jackson, Eli R. Makus, and Lisa Tang. Thanks, too, to UC Davis law librarians Erin Murphy, Peg Durkin, and Susan Llano for their indispensable assistance. 
Finally, Professor Pruitt argues that sexual slander law was an additional way in which women's sexual propriety was commodified, ultimately to the benefit of their fathers and husbands. She argues that a preferable scheme would have permitted courts more expansive jurisdiction over sexual slander claims, as well as power to provide a more expansive array of remedies. That is, drawing on the remedies of apology and repentance that had been available in English ecclesiastical courts-remedies remarkably similar to retraction and declaratory judgment remedies that are associated with contemporary defamation reformnineteenth-century courts could have avoided propertizing women's virtue. At the same time, they could have provided appropriate remedies to more of the women who had been injured by sexual slander.

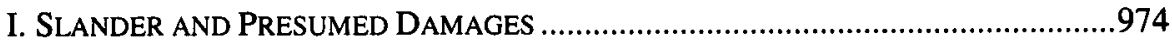

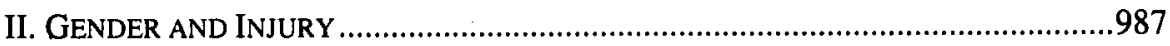

III. CONCEPTIONS OF INJURY IN SEXUAL SLANDER CASES .................................991

A. Relational Injuries as Pecuniary Injuries ................................................992

B. Emotional Injuries and Their Pecuniary Consequences...........................996

C. Emotional Injuries as Nonpecuniary Injuries and Causation Challenges

Rejection of Relational Injuries

E. Other Indicia of Women's Virtue as Property ......................................1012

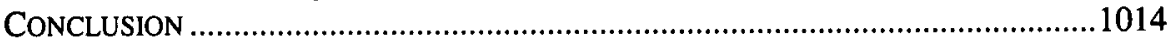


The delicacy and frangibility of the female character is scarcely realized in poetic fancy. The breath of slander withers it in an instant. Touch it and it is annihilated.

State v. Brunson \& Miller $(1831)^{1}$

As this quote attests, a woman's sexual propriety has long been a significant measure of her worth in our society. ${ }^{2}$ In the face of this reality, women have called on defamation law to provide redress for injury from communications that undermine their reputations for this virtue that society has seen as so important. ${ }^{3}$

1. 18 S.C.L. (2 Bail.) 149, 150 (1831).

2. Professor Andrew King, who has written about the law of sexual slander in the nineteenth century, has observed how the evolution of sexual slander in the post-Revolutionary period caused women to be "under[stood]" in "terms of sexual reputation," helped to "maintain a gendered vision of law," and caused women to be "endowed with a nature rooted in dependence." Andrew J. King, Constructing Gender: Sexual Slander in Nineteenth-Century America, 13 LAW \& HIST. REV. 63, 67 (1993). "In dealing with sexual slander, courts and legislatures carried forward the idea that sexual propriety constituted the principal element of female reputation. As part of the social underpinning of society, middle-class men esteemed chastity for unmarried women and fidelity for their wives." Id. at 68. Finally, King has opined that "[c]hastity epitomized female virtue; its value required seeing a woman's function as purely sexual." Id. at $69 \mathrm{n} .25$. See also John D'EMILIO \& Estelle FreEdMAN, INTIMATE MatTERs: A History of SEXUALITY IN AMERICA 70-71, 132-33 (2d ed. 1997) (discussing a dichotomy between "pure" and "fallen" women).

Just as nineteenth-century courts often waxed poetic about female virtue, they did not shy from moralizing about the decline of society, as evidenced by fallen women. Having held that a defendant's statement about the plaintiff was not justified, one Georgia court wrote in 1860:

If parents will permit their daughters to grow up without restraint-to play the wanton in the streets and public places of the city-even if they escape actual pollution, they are not entitled to the same compensation as should be awarded to the modest maiden, who, should ever an impure thought intrude itself, would crimson her cheek with a burning blush, though alone in the solitude of her chamber, and concealed from mortal eye by the deep shades of midnight. This would be to confound all distinction between the pure and impure.

Slander verdicts, however enormous, cannot preserve the reputation of our daughters, if we suffer them to grow up without domestic restraint; nor will the Founder of families hold such parents guiltless. Governments may enact salutary laws, the ministry may thunder weekly from their pulpits the lessons of the Law, Courts may execute judgment in righteousness, but unless family discipline be enforced, all other efforts will be in vain, to save the rising generation from ruin and wretchedness and the land from destruction. Where, amongst us, are the representatives of the women-ay, and the men, too, of the olden time? And yet, to these hot-house plants with all their immaturity of body and mind, are soon to be committed the destinies of this mighty nation! Who does not tremble in view of this fact?

Beggarly v. Craft, $31 \mathrm{Ga} .309,1860$ WL 2385, at *5 (1860).

3. Professor Diane Borden has written about the construction of women's sexuality in defamation cases, arguing that courts speak of women's reputation in terms of virtue and men's reputations in terms of honor. She also discusses the primacy that a woman's reputation for chastity had in the nineteenth century and argues that this primacy continues into the twentieth century. Diane Borden, Reputational Assault: A Critical and Historical Analysis of Gender and 
Almost since cases began to be reported in most U.S. jurisdictions and for well over a century in the remaining states, spoken statements impugning a woman's chastity ${ }^{4}$ have been deemed slander per se. ${ }^{5}$ At common law, this designation meant that damages are presumed from such statements and the plaintiff need not prove such damages in order to state a prima facie case. ${ }^{6}$ Before this slander per se category was recognized, however, women suing for sexual slander had to prove so-called "special damages" ${ }^{\prime 7}$ in order to state a cause of action for slander. ${ }^{8}$ Judicial opinions from that

the Law of Defamation, 75 JournaLISM \& MASS COMM. Q. 98, 99-101, 107 (1998) [hereinafter Borden, Gender and Defamation].

4. "Impugning chastity" is a term of art often associated with the communications at issue in these cases, which are sometimes referred to collectively as about "sexual slander." While chastity is rarely expressly defined, the cases make clear that it refers to whatever sexual behavior is considered inappropriate in a given place, at a given time. Specific allegations and other terms used in nineteenth-century cases include so-called "lascivious carriage," prostitution, premarital sex, adultery, "whoring," and bestiality. See, e.g., Frisbee v. Fowler, 2 Conn. 707, 707 (1818); Kennedy v. Gifford, 19 Wend. 296, 297 (N.Y. Sup. Ct. 1838).

5. King, supra note 2, at $72-73$ (discussing history of the recognition of this slander per se category in the United States).

6. A similar transition may be observed in English defamation law. English law courts did not consider statements impugning a woman's chastity to be slander per se until the Slander of Women Act, 54 \& 55 Vict., c.51 (1891) (Eng.). See also infra notes 59-64 and accompanying text.

It should be noted that while the per se designation at common law was accompanied by a presumption of damages, this rule is not necessarily followed in the constitutional era of defamation law. See infra note 53 and accompanying text.

7. For an excellent discussion of the history and precise meaning of this term, see David A. Anderson, Reputation, Compensation, and Proof, 25 WM. \& MARY L. Rev. 747, 759-60 (1983) [hereinafter Anderson, Reputation]. The Restatement (Second) of Torts says special harm is "the loss of something having economic or pecuniary value." RESTATEMENT (SECOND) OF TORTS, $\S 575$ comment b (1977). It is sometimes expressed as an out-of-pocket loss.

8. Some states adopted this slander per se category by legislation; others did so judicially. King, supra note 2, at 72-73. Among the earliest states to embrace this category were North Carolina in 1808 (1808 N.C. Sess. Laws 570), Kentucky in 1811 (Act of 1811, in 4 W. LITTELL, THE STATUTE LAW OF KeNTUCKY 385 (1814), and Indiana in 1813 (1813 Ind. Acts 110). Other states are discussed in King, supra note 2, at 86-87. The latest state to adopt the slander per se category was New York, in 1871 (1871 N.Y. Laws 219). Georgia was also relatively late in doing so, making such statement slander per se only in 1852 . $1852 \mathrm{R}$. H. CLARK ET AL., THE CODE OF THE STATE OF GEORGIA 512 (2d 1852). An 1859 statute limited its protection to white women, stating that "Any charge or intimation against a free white female of having sexual intercourse with a person of color, is slanderous without proof of special damages." Id. While Maryland adopted the rule in 1838 , it nevertheless adjudicated a number of sexual slander cases in which women sought to prove special damages to complete their prima facie cases. $1838 \mathrm{Md}$. Laws 1 14. This legislative act has been viewed as a response to Stanfield v. Boyer, 6 H. \& J. 248 (Md. 1824), in which the court said that calling an unmarried woman a "whore" did not state a cause of action. The Maryland law restricted the slander per se category to "words spoken maliciously touching the character for chastity of unmarried women." Maryland amended the law in 1881 to cover such statements about all women, whether married or single. $1881 \mathrm{Md}$. Laws 444. In California, the legislature in 1874 created a category of slander per se to include statements that "impute[] to him impotence or a want of chastity." CAL. CIV. CODE $\$ 46$ (1874). Although the masculine pronoun was used, the provision apparently applied to plaintiffs of both 
period reveal an interesting dichotomy between injuries that were deemed cognizable in defamation law and those that were not. In particular, U.S. courts of that era did not recognize a woman's cause of action if she alleged only a purely personal injury, such as emotional upset and attendant physical illness as a consequence of the offending statement. This denial persisted even when the plaintiff established that she had suffered a pecuniary loss because she was forced to employ servants to perform tasks she was too ill to perform herself. ${ }^{9}$ In short, courts in these cases failed to identify the requisite special damages even when the plaintiff established an out-of-pocket loss that flowed from the statement. If, on the other hand, a female plaintiff (or her husband, ${ }^{10}$ father, ${ }^{11}$ or prochein $a m i^{12}$ suing on her behalf) was able to show an injury that the

sexes and viewed a false assertion of impotence as the equivalent to a statement undermining chastity. See also generally Borden, Gender and Defamation, supra note 3, at 101-04 (discussing the language in these statutes that made sexual slander per se slander and assessing the gender politics reflected by these laws).

9. See infra notes 186-92. Courts also often expressed skepticism that emotional distress injuries were actually the consequence of the defamatory statement. See infra notes 186-220 and accompanying text.

Plaintiffs who stated a slander per se claim could recover both for her pecuniary loss and mental anguish. See Zeliff v. Jennings, 61 Tex. 458, 467 (1884) (collecting cases and stating that "wounded feelings ... enfeebled health and incapacity to perform labor" could all be considered by the jury in determining the damages to be awarded to a woman who stated a slander per se claim). Courts of this era often observed that sexual slander would naturally have a profound impact on a woman's feelings. See, e.g., Malone v. Stewart, 15 Ohio 319 (1846) (noting this "deepest wound" on a young girl's feelings and articulating a "profound respect for female character and feeling"); Kennedy v. Gifford, 19 Wend. 296, 330-31 (N.Y. Sup. Ct. 1838) ("difficult to conceive of words ... more harrowing to the feelings of a female whose moral sense was not totally depraved").

10. In the nineteenth century, married women typically were not permitted to bring suit. Rather, their husbands brought suit on their behalf, or jointly with them. See, e.g., Long v. Long, $4 \mathrm{~Pa} .29$ (1846) (husband and wife were proper parties to action when wife was defamed). Single women-or feme soles as they were called-were permitted to sue on their own behalf. Indeed, those over the age of twenty-one were required to do so. See, e.g., Wilms v. White, 26 Md. 380 (1867). The defamation cases of this era reveal sometimes complex and unclear rules around these procedure and standing issues. See, e.g., Stroop v. Swarts, 12 Serg. \& Rawle 76 (Pa. 1824) (judgment in favor of husband and wife for slander of the wife arrested before the wife's death; writ of error does not survive to husband). Zeliff $v$. Jennings provides an interesting discussion of the husband's responsibility for his wife's torts, not because of the marriage itself but because of the presumption created due to the "nature of the control given him by law and social usage over her conduct and actions." Zeliff, 61 Tex. at 471 . The court there states that "it would be difficult, if not impossible, for the courts to determine when [the wife] had acted at her own instance, and when she was guided by [her husband's] dictation." $I d$.

11. Fathers often sued on behalf of daughters who were under twenty-one years of age. See, e.g., Lester v. Corley, 13 So. 467 (La. Ct. App. 1893) (father sued on the basis of statements impugning the chastity of fourteen-year-old daughter; alleged that he and "every member of his family" had been injured, in addition to her); Hardin v. Harshfield, 12 S.W. 779 (Ky. 1890) (father sued on behalf of twenty-year-old daughter when report that young woman had farted in a public place caused loss of her marital engagement); Taylor v. Moran, $61 \mathrm{Ky} .127$ (1863) (father sued on behalf of daughter who was alleged to be a "whore"; trial court jury awarded $\$ 6000$ in damages); Brawner v. Sterdevant, 9 Ga. 69 (1850); Shields v. Cunningham, 1 Blackf. 
court recognized as pecuniary, her claim was cognizable in slander. Even the "most trifling loss," 13 if seen to have a pecuniary character, was sufficient to constitute special damages, thereby completing the plaintiff's prima facie case. Of particular interest in these nineteenth-century cases is that establishing a statement's adverse impact on a woman's social and personal relationships-that the offending statement caused her a "loss of hospitality and society" 14 or a broken marital engagement-was seen as establishing a pecuniary injury. The pecuniary nature of the injury was identified in the monetary value associated with these relationships, including such items as the actual value of being invited to dine in the homes of others or the financial security associated with marriage. ${ }^{15}$

86 (Ind. 1820) (case brought on behalf of girl, "an infant, by her next friend" who was her father, when she was said to have committed fornication with a man).

12. This term refers to a guardian or "next friend" suing on behalf of one without legal capacity to sue on her own behalf. See, e.g., Wilms, $26 \mathrm{Md}$. at 382 . Single women-or feme soles as they were called-were sometimes permitted to sue on their own behalf. Indeed, those over the age of twenty-one were required to do so. See, e.g., id.

13. Olmsted v. Miller, 1 Wend. 506, 508 (N.Y. Sup. Ct. 1828). In that case, the "trifling loss" was refusal to serve the plaintiff at a public house. Other courts spoke in terms of the requirement being "slight." Linney v. Maton, 13 Tex. 449, 453 (1855) (citing Bradt v. Towsley, 13 Wend. 253 (N.Y. Sup. Ct. 1835), Moore v. Meagher, 1 Taunt. 39, 127 Eng. Rep. 745 (C.P. 1807), Moody v. Baker, 5 Cow. 351 (N.Y. Sup. Ct. 1826), and Douglass v. Tousey, 2 Wend. 352 (N.Y. Sup. Ct. 1829)).

Interestingly, a similar dichotomy between injuries to relationships, which are cognizable at law, and those to feelings, which are not, is evident also in much more recent cases. In Wineholt v. Westinghouse Electric Corp., the court wrote that "By special damage in such a case is meant pecuniary loss; but the term also includes loss of substantial hospitality of friends."' 476 A.2d 217, 221 (Md. 1984) (quoting 1 PoE's Pleading AND PRACTICE $\$ 174$ (6th ed. 1970)). The Wineholt court went on to describe sympathetically the emotional distress claim:

The mental anguish of one whose integrity is impugned is as difficult to describe to those who have never endured it, as it is for them to understand. The sneers and sarcasms, even of those who should be one's friends, are not the subject of pleadings, nor is it necessary initially to detail the reasons why the malignity spread, or how it adversely affected the maligned's vocation until proofs are called for or particulars demanded.

Id.

14. See, e.g., Moore, 127 Eng. Rep. at 745 . In that matter, words imputing "incontinence" to the female plaintiff caused special damages. See infra notes 16-19 and accompanying text for more detail. While it was suggested somewhat pejoratively in that case, "if this action lies, no words are not actionable with the aid of an ingenious special pleader," the appellate court nevertheless affirmed that special damage was proved. Chief Justice Mansfield concluded: "We do not know how to say that this is not a special damage, sustained in consequence of words imputing infamy." Id. at 747.

15. Keeping women "marriageable" was clearly a matter of great concern to fathers of the time, and it thus became a concern of judges, too. See King, supra note 2, at 67 . King notes "[t]he assumption that any injury to reputation endangered an unmarried woman's chances of marriage" and argues that this motivated judges' willingness to recognize sexual slander as slander per se. Id. As a related matter, he argues that middle-class judges saw women as taking "their place in the community" through marriage. Id. at 73. For women of this era, "success meant marrying well" and marriage was the goal for young women. $1 d$. at $72 \mathrm{n} .40$ (citing 
One case oft-cited in U.S. jurisprudence on this issue is Moore v. Meagher. ${ }^{16}$ There, an English court observed the plaintiff had lost "an income derived from the bounty of others, which ... we must assume would have continued if the Defendant had not spoken these words." "17 That court noted that, prior to the offending statement, the plaintiff had been "received and entertained in [the houses of her friends] and [been] found and provided by them respectively with meat and drink, gratuitously . . to the great reduction of her necessary expenses of living and maintaining herself, and the great increase of her riches." 18 The court concluded that the plaintiff had "lost all those valuable benefits . . . and [been] obliged to incur a much greater expense in her necessary living and [support], to wit, the annual amount of $£ 100$." 19 The court's contorted conversion of a relational injury into a pecuniary one may help to explain a line of thinking evident in subsequent U.S. cases.

In these later U.S. cases, alienation in personal relationships came to be seen as a martketplace-type injury, with a calculable dollar value. Thus, although individual plaintiffs might have concurred with the Biblical adage that "a good name is rather to be chosen than great riches" ${ }^{20}$ because they viewed their injuries as damaging in a highly personal and largely intangible way, courts recognized these plaintiffs' injuries only by articulating them in terms of the "riches" they represented.

Courts of this era recognized women's sexual slander claims only by characterizing the injury suffered as a variety of property damage, an injury cognizable in the marketplace relevant for women-that for "marriageability." For it was by marriage that women were seen as fulfilling their destinies and assuming their appropriate roles in society. ${ }^{21}$ Essentially, courts identified harms that they considered worthy of redress

Suzanne Lebsock, The Free Women of Petersburg: Status and Culture in a Southern Town 166 (1984); Hendrik Hartog, Marital Exits and Marital Expectations in Nineteenth Century America, 80 GEO. L.J. 95 (1991)); Lawrence M. Friedman, Name Robbers: Privacy, Blackmail and Assorted Matters in Legal History, 30 HOFSTRA L. REv. 1093, 1103-05 (2002). Professor Friedman has expressed the importance of marriage thus: "Marriage for most respectable women was absolutely crucial, because it was the gateway for the only truly acceptable mode of life." Id. at 1097. See also Jane E. Larson, "Women Understand So Little, They Call My Good Nature 'Deceit'": A Feminist Rethinking of Seduction, 93 CoLUM. L. REV. 374,383 (1993). Among cases where a broken marital engagement was the damage alleged is Hardin v. Harshfield, 12 S.W. 779 (Ky. 1890).

16. 127 Eng. Rep. at 747 (citing Hartley v. Herring, 8 T.R. 130, 101 Eng. Rep. 1305 (K.B. 1799)).

17. Id.

18. Id. at 745 .

19. Id.

20. Proverbs 22:1.

21. One court expressed the nature of the injury from sexual slander with these words: The nature of the charge is calculated to destroy her character, cut her off from virtuous society, prevent her from forming that connection in life in which are centered all her hopes and affections, and consign her to dependence, unhappiness and misery, or competency from infamous prostitution. Such a charge, in its extent and influence upon character, or in its consequences, is vastly more injurious to a female than to our sex. When believed, it places a female beyond the pale of society. Seldom seen, they can neither fly from, nor outlive the disgrace, but must pine and wither, and live under it, a loathed and filthy weed, whose touch is 
in these cases only by conceptualizing the injury as one to the property their reputations for virtue represented. ${ }^{22}$ In so doing, courts recognized as much, if not more, an injury to the women's fathers and husbands, rather than to the women themselves. ${ }^{23}$ This was so because either father or husband was financially responsible for all but the rare woman who was both unmarried and over the age of twenty-one.

My central claim here is that by considering the U.S. defamation cases from this era before statements impugning chastity were deemed slander per se, we can see how women were compelled to articulate their injuries in a way that reflected masculine values and interests: property, the marketplace, and economic injuries. ${ }^{24}$ Thus, my Article builds on the work of feminist scholars who have revealed the ways in which tort law is gendered, particularly with respect to conceptions of injury. ${ }^{25}$ Nineteenth-

contamination.

Sexton v. Todd, Wright 316, 320-21 (Ohio 1833) (statement charged the plaintiff with having a child out of wedlock).

Other courts also expressed particular sympathy to unmarried women who had been sexually slandered, particularly because it hurt their prospects for marriage. When the "young girl" plaintiff in Malone v. Stewart, was called a hermaphrodite, the court observed that this "excludes her from social intercourse and all hopes of marriage." Elsewhere, the court wrote that the words prevented the plaintiff "from occupying such position in society as is her right, as a woman." 15 Ohio 319, 320, 321 (1846). See also supra note 15 and accompanying text.

22. At least one scholar has drawn a contrary conclusion. Andrew King, who considered some of these issues in a 1995 article, observed that judicial "recognition of a non-economic justification for the protection of reputation reflected a broader re-orientation in the law of defamation from the protection of 'reputation as property' to 'reputation as dignity."'See King, supra note 2, at 69-70 (citing Robert C. Post, The Social Foundation of Defamation Law: Reputation and the Constitution, 74 CALIF. L. REV. 691 (1986)). For reasons more fully articulated below, I disagree with this conclusion and argue that the injury was conceived as one to property. See infra Part III.

This propertization phenomenon evident with respect to sexual slander echoes the theory underlying the tort of seduction. A father's right to sue his daughter's seducer was based on an analogy to a master-servant relation, and the injury was the father's loss of his daughter's services, usually as a result of her pregnancy. Larson, supra note 15, at 382. See also Friedman, supra note 15, at 1099 (noting the "tremendous interest" parents and husbands had in "protecting the chastity of daughters and wives").

23. The nineteenth-century perception that a father, separate from his daughter, suffered an injury when her virtue was besmirched is also evident in the law of seduction and breach of promise to marry. In such cases, courts allowed both father and daughter to recover punitive damages for the same wrongful act by the defendant, indicating that two separate injuries were being redressed. See Thomas B. Colby, Beyond the Multiple Punishment Problem: Punitive Damages as Punishment for Individual, Private Wrongs, 87 MiNN. L. REv. 583, 624-25 (2003).

24. See infra text at notes 95-104 explaining how these categories of injuries may be seen as masculine, or associated primarily with men.

25. See, e.g., Leslie Bender, A Lawyer's Primer on Feminist Theory and Tort, 38 J. LegaL EduC. 3 (1988); Leslie Bender, An Overview of Feminist Torts Scholarship, 78 CORNELL L. REv. 575 (1993); Cynthia G. Bowman, Street Harassment and the Informal Ghettoization of Women, 106 Harv. L. Rev. 517 (1993); Martha Chamallas, The Architecture of Bias: Deep Structures in Tort Law, 146 U. PA. L. REV. 463 (1998); Martha Chamalias \& Linda K. Kerber, Women, Mothers and the Law of Fright: A History, 88 MiCH. L. Rev. 814 (1990); Larson, supra note 15; Jean C. Love, Discriminatory Speech and the Tort of Intentional Infliction of 
century courts' characterization of these women's injuries as harm to property seems particularly ill-fitting because the injuries about which these women complained often were not pecuniary, or at least not primarily so. Rather, the harms they suffered were injuries to emotional and physical well-being, dignity, and essentially personal relationships. ${ }^{26}$ Nevertheless, courts stubbornly refused to provide redress for these injuries-and therefore to see these claims as cognizable in slander-unless they could articulate the injuries as pecuniary. Observations about the nature of the injuries that could be recognized as pecuniary and therefore valid, compared to those denied as nonpecuniary, reveal a property or market orientation of defamation law.

An analysis of these cases provides an opportunity to consider the gender politics of women's use of defamation law to redress sexual slander during this era. On the one hand, these suits might be seen as subversive, as women came to present their injuries in a way that enabled judges to characterize them as pecuniary. That is, these plaintiffs came to articulate as their "special damages" injuries recognized in the marketplace, even if they might not have intuitively conceptualized their injuries in that way. On the other hand, it might be said that the women's interests were subverted to those of the men in their lives-their husbands, fathers, and even their lawyers-as their injuries came to be articulated in a way that made them public and cognizable in the marketplace, and therefore in law. In so doing, these injured women were compelled to embrace masculine values in order to accomplish the goal of redress. These women's sexual behavior was not only commodified, it was elevated to a status of the utmost importance, with courts often expressly recognizing their husbands and fathers as its proprietors, the true parties in interest in these matters. ${ }^{27}$ The question remains, then, whether it was it preferable for these slandered women to have redress on the law's (masculine) terms rather than no redress at all?

My analysis proceeds in three parts. First, I provide an overview of the aspects of defamation law that are relevant to my argument, specifically the law on slander per se and the related damages rules. This includes a brief history of the English law of sexual slander from which the U.S. jurisprudence evolved. It also includes a discussion of different theories of reputation and injury associated with defamation law, focusing on the conception of reputation as property. Second, I discuss how these different conceptions of injury may be seen as gendered, reflecting values associated predominantly with either women or men. Finally, I offer detailed discussions of U.S. cases from the era at issue, illustrating how courts recognized special damages arising from sexual slander only when the plaintiff averred a property-type injury to her reputation. I conclude with observations and questions about the gender politics of the evolution of sexual slander law in the nineteenth century.

Emotional Distress, 47 WASH. \& LEE L. Rev. 123 (1990).

26. See infra notes 43-48 (Post's discussion of reputation as dignity).

27. See, e.g., Olmsted v. Brown, 12 Barb. 657 (N.Y. Gen. Term 1852), discussed infra at notes 208-13; Lynch v. Knight, 9 H.L.C. 577, 11 Eng. Rep. 854 (H.L. 1861), discussed infra at notes $108-17$ 


\section{SLANDER AND PRESUMED DAMAGES}

Of all the treasures cherished by a woman, her reputation for chastity is the dearest.

$$
\text { Jones v. Jones }(1883)^{28}
$$

A few words about relevant defamation law basics are helpful at the outset. Defamation, of course, redresses injury to reputation, the lowering of the plaintiff in the esteem of the community by virtue of a false statement. The essence of the injury is expressed in many different ways. It was, for example, defined in the late nineteenth century to include statements injuring a plaintiff in his "credit and reputation" and bringing him "into public scandal, infamy, and disgrace with and amongst all his neighbors, friends, and acquaintances." 29 The Restatement (Second) of Torts summarizes that "[a] communication is defamatory if it tends so to harm the reputation of another as to lower him in the estimation of the community or to deter third persons from associating or dealing with him." ${ }^{, 30}$ Thus, the tort might be characterized as primarily concerned with relationships because it is about the willingness of persons to interact with one another. ${ }^{31}$

Professor Robert Post has written about the theoretical foundations of defamation law, including extensive discussions of the concepts of reputation as property,

28. 60 Tex. 451, 460-61 (1883).

29. Erwin v. Dezell, 19 N.Y.S. 784 (N.Y. Gen. Term 1892). A slightly later case defined a defamatory statement as one tending to "impeach the honesty, integrity, virtue, or reputation, or publish the natural or alleged defects, of one who is alive, and thereby expose him to public hatred, ridicule, or obloquy, or to cause him to be shunned or avoided or to injure him in his office, business or occupation." Cronin v. Zimmerman, 88 N.E. 718, 719 (Ind. 1909).

30. RESTATEMENT (SECOND) OF TORTS, § 559 (1977).

31. This Restatement provision indicates that the law is very concerned about relationships, with its focus on our willingness to interact with one another. Indeed, one of the Restatement comments, labeled "social aversion," states:

A communication may be defamatory of another although it has no tendency to affect adversely the other's personal or financial reputation. Thus, the imputation of certain physical and mental attributes such as disease or insanity are defamatory because they tend to deter third persons from associating with the person so characterized.

Id. at comment $\mathrm{c}$.

These two sentences appear, at first blush, to contradict one another. The first notes that statements may be defamatory, even though they do not injure a person's reputation. The second indicates that reputational injury-and the deterrence of third persons from dealing with the plaintiff-is the essence of the injury for which defamation law provides redress. The two can be reconciled only if "personal and financial reputation" are construed as being unrelated to the social relations that might be affected by a defamatory communication. Thus, the Restatement might be read to recognize a distinction between the marketplace or property-type concept of reputation and one that defines or conceives of reputation as related to the willingness of others to engage in social or other types of intercourse with the defamed party, the latter concept being primarily relational. While the law of defamation sees a distinction between these harms, historically it has provided redress for both. 
reputation as honor, and reputation as dignity. ${ }^{32}$ He notes the presence of each of these conceptions in defamation doctrine, concluding that the concept of reputation as property enjoys the most prominent presence of the three in contemporary case law. ${ }^{33}$

Under the reputation-as-property model, reputation is a sort of "goodwill" associated with an individual. An asset that is capable of measurement in the marketplace, reputation is a product of individual effort, capable of being earned and therefore varying in value from person to person. ${ }^{34}$ This concept is reflected, for example, in the image of the craftsman who labors to achieve a good reputation for quality workmanship. ${ }^{35}$ Reputation as property presupposes the connection of all persons through a market, which determines the property's value. The law of defamation protects individuals by ensuring that reputation is not unfairly deprived of the value that the individual has created through his or her efforts in the market. Because the worth of an individual's reputation varies with the marketplace conditions, reflecting the market's values at any given time, this theory of defamation law protects only the aspects of reputation that the market can measure. ${ }^{36}$

32. Robert C. Post, The Social Foundation of Defamation Law: Reputation and the Constitution, 74 CALIF. L. Rev. 691 (1986). See also Randall Bezanson \& Brian C. Murchison, The Three Voices of Libel, 47 WASH. \& LEE L. REv. 213, 213 (1990) (discussing the "multiple dimensions" of the libel tort, including "substantive, sociological, and jurisprudential" differences among its various conceptions, in the common law, under the constitution, and as declaratory judgment).

33. Post, supra note 32, at 693 . As Post expresses it, " $[t]$ he concept of reputation that is most easily available to contemporary observers is that of reputation in the marketplace." Id.

34. Thomas Starkie wrote in his 1826 treatise,

The numerous gradations of rank and authority, the honours and distinctions extended to the exertion of talent in the learned professions, the emoulument acquired by the mechanical skill and ingenuity, under the numerous subdivisions of labour, the increase of commerce, and particularly the substitution of symbols for property in commercial intercourse - all in different degrees, connect themselves with credit and character, affixing to them $a$ value, not merely ideal, but capable of pecuniary admeasurement, and consequently recommending them as the proper objects of legal protection.

Thomas Starkie, A Treatise on the Law Of Slander, Libel, SCandalum Mangatum and FALSE RUMOURS xx (New York, Collins \& Hannay 1832) [hereinafter STARKIE ON SLANDER] (emphasis added), quoted in Post, supra note 32, at 694.

35. Post, supra note 32, at 694.

36. Id. at 696. Thus, because the significance of chastity as a component of a woman's worth has diminished in the modern era, surely now a woman's reputation is comprised of and measured based on more than sexual virtue. While the commercial marketplace is the model or prototype for the "reputation-as-property" concept, this concept finds application outside business relationships. That is, defamation law redresses harm to character in contexts that are not strictly related to the commercial marketplace, because the reputation-as-property concept views character "as the fruit of personal exertion," and it seeks to protect the investment one makes in his or her reputation. Id. at 694. "Reputation itself owes its being and importance chiefly to the various artificial relations that are created as society advances." Id. at 694 (quoting STARKIE ON SLANDER, supra note 34).

Interestingly, Professor Post specifically argues that the concept of reputation as property is inconsistent with the common law's presumption of harm to reputation in slander per se and certain libel cases. As he notes, the presumed damages rule "puts defamation law in the business 
As Townshend, another nineteenth-century scholar, explained, defamation law's "protection is to the property, and not to the reputation ... [P]ecuniary loss to the plaintiff is the gist of the action for slander or libel.",37 Thus, in explaining what defamation law protects, Townshend went as far as to disaggregate "property" entirely from "reputation." He thereby clarified that, to the extent there is a conflict or inconsistency - to the extent that reputation is about something other than propertydefamation law compensates injury to the latter rather than to the former. ${ }^{38}$

Two other conceptions of reputation that are less apparent and less discussed in cases and commentary are reputation as honor and reputation as dignity. ${ }^{39}$ Contrary to property theory of reputation, individuals do not earn honor through their efforts; rather, society bestows such honor as part and parcel-as an emolument, if you willof the individual's social role. ${ }^{40}$ While a good reputation is not earned through an individual's effort, it may nevertheless be lost by dishonorable behavior. Further, reputation-as-honor is a "public good," not the private possession of the individual that we contemplate with the reputation-as-property model. This honor-oriented view of reputation sees it as incommensurate with the values of the market. ${ }^{41}$ Indeed, "dishonor is a fall from grace in the most comprehensive sense-loss of face in the community, but also loss of self and separation from the basic norms that govern human life.,"42

of compensating individuals for harms which, from the perspective of reputation as property, may well be non-existent." Id. at 697. Thus, Professor Post concludes, this rule may work an unearned windfall in the marketplace.

37. John Townshend, A Treatise on the Wrongs Called Slander and Libel 108-09 (1877), quoted in Post, supra note 32, at 696.

38. The suggestion is that reputation is associated with other interests, probably including dignity and honor, and that property, with which the law concerns itself, is quite distinct.

39. Post, supra note 32, at 699-712.

40. Id. at 700. Honor is a "form of reputation in which an individual personally identifies with the normative characteristics of a particular social role and in return personally receives from others the regard and estimation that society accords to that role." Id.

41. "Honor cannot be converted into a continuous medium of exchange. It cannot be bought and sold like goodwill, but is instead attached to specific social roles." Id. at 700-01.

42. Post, supra note 32, at 701 (quoting Peter L. Berger et AL., The HoMeless Mind: Modernization and CONSCIOUSNESS 90 (1973)). Defamation law, then, can be seen as responding to the grievance by vindicating the plaintiff's honor, which is more important than compensating him financially. With its function of vindication, the honor-oriented view of defamation is linked most closely to criminal libel, which made the truth of an offending statement immaterial. In choosing to proceed by criminal rather than civil libel, the plaintiff sought to avenge his name to punish the libeler, rather than to disprove the libel. Id. at 704. In short, he sought vindication. As a related matter, the presumption of damages at common law, which is arguably unjustified under the property theory of reputation, can be viewed as permitting juries to fulfill a goal of vindicating the plaintiff's honor in the community, rather than compensating him. Id. at 706 (citing Anderson, Reputation, supra note 7, at 750).

Similar sentiment is occasionally reflected in the sexual slander cases, as in one in which the court wrote: "Character is more dear to a person than property." Long v. Long, $4 \mathrm{~Pa}$. 29, 31 (1846). It is also reflected in the oft-expressed dichotomy between "temporal" injuries and "spiritual" ones. See also Davis v. Gardiner, 4 Co. Rep. 16b, 76 Eng. Rep. 897 (1593) (the spiritual or ecclesiastical courts were in favor of redressing dignitary injuries, and law courts were seen as redressing injuries only if they were pecuniary). See also supra note 32 and accompanying text. 
The dignity-oriented view of reputation is similarly attuned to the significance of an individual's membership in the community and also embraces the idea that the marketplace cannot measure the value of reputation, which cannot be restored through monetary damages. ${ }^{43}$ This view of reputation "assumes that the identity of an individual is in significant ways the product of the social connections by which he is embedded in and attached to a community." 44 Individuals do not earn dignity; rather, it is simply essential and intrinsic in every human being. ${ }^{45}$ In redressing a dignity interest, then, defamation law restores to the plaintiff "the respect (and self-respect) that arises from full membership in society." 46 At the same time, defamation law maintains community identity as it authorizes juries to sanction those whose communications trespass the community's "bounds of propriety" ${ }^{, 47}$ or breach the rules of civility. ${ }^{48}$

43. Post distinguishes between the dignity and honor concepts. Thus, "honor is concerned with attributes of personal identity that stem from the characteristics of particular social roles, whereas dignity is concerned with the aspects of personal identity that stem from membership in the general community." Post, supra note 32, at 715.

44. Id. at 711. Post argues that the definition of defamatory words as "those injuring 'the reputation of another by exposing him to hatred, contempt, or ridicule' was clearly oriented toward the concept of reputation as dignity, since it stressed the stigmatizing harms that occur when rules of civility are violated." Id. at 717 (quoting Parmiter v. Coupland, 6 M. \& W. 105, 108, 151 Eng. Rep. 340, 342 (Ex. Ch. 1840) (per Parke, B.)). I would argue that this definition of defamatory meaning could also refer to the concept of reputation as property, injury to which is shown by the impact on one's relationships, one's standing in the marketplace.

45. Id.

46. Id. at 711. The community-standing concept of injury is reflected in many cases where caurts are grappling with the nature of the injury from sexual slander, and even when courts were considering what should constitute slander per se. For example, in Dial v. Holter, the Ohio Supreme Court, in determining which crimes should be included in the per se category based on allegations of the commission of a crime, wrote that when the act would exclude the person from the "favor and countenance of all moral persons... The nature and turpitude of the act charged are the criterions [sic] by which to decide whether the injury is such as to be the foundation of an action." 6 Ohio St. 228, 242 (1856). Similarly, in Ivester v. Coe, the injury pleaded by the sexually slandered woman was that her "'neighbors, citizens, and associates" have 'withdrawn their confidence and companionship, wholly refusing and still refusing to associate with [her] as in the past."'127 S.E. 790, 792 (Ga. 1925).

47. Post, supra note 32 , at 713.

48. Id. at 711. Interestingly, defamation law's policing of civility and community norms is similar to the ways in which society policed women's compliance with community norms with the very statements that constituted sexual slander. For a discussion of the latter dynamic, see King, supra note 2, at 75 . Associated with redress of an injury to dignity are the so-called "Insulting Words" and "Anti-Dueling" statutes adopted by three states in the nineteenth century. Note, The Actionable Words Statute in Virginia, 27 VA. L. Rev. 405 (1941) (discussing MISS. CODE ANN. § 11 (1930); VA. CODE ANN. § 5781 (Michie Supp. 1940)); W. VA. CoDE ANN. § 5471 (Michie 1937). The legislatures of Mississippi, Virginia, and West Virginia each adopted legislation that provided a cause of action for words that insulted the plaintiff, whether or not those words were communicated to a third party, as is required in defamation law. The Virginia statute was the first of the three, passed in 1810, and like the others was aimed at preventing duels, which might otherwise be initiated by those who insulted. Id. at 405 . In this sense, the statutes might be seen as responding to a problem uniquely associated with men-the tendency to resort to violence to redress a grievance. See also J.B. Hutton, Jr., The Unconstitutionality of the Anti-Dueling Act of Mississippi, 7 Miss. L.J. 390 (1935). 
In summary, then, the property theory of defamation law views reputation as an earned asset capable of valuation in the marketplace. Alternative theories, oriented to honor and dignity, are more attuned to the damage that defamatory statements do to one's relationships and community standing, values that are not capable of monetary estimation.

Defamation includes the twin torts of libel and slander, the former for written communications and the latter for spoken communications. Prosser once said that "a great deal of the law of defamation . . . makes no sense," ${ }^{, 49}$ and this is certainly true with respect to the complex damages rules associated with the tort. ${ }^{50}$ While the gist of the injury is harm to reputation, once such harm is proved or presumed, compensation for wounded feelings and physical illness is also permitted. ${ }^{51}$ It is a long-standing rule in the Anglo-American common law that damages are presumed from a libelous communication, ${ }^{52}$ though this has certainly changed in the constitutional era of

49. W. Page Keeton Et. Al., Prosser and Keeton on The Law of Torts $\$ 111$, at 771 (5th ed. 1984).

50. Interestingly, Professor Post argues that, with defamation law, "[p]otential for harm, rather than actual harm, is the crux of the wrong." Post, supra note 32, at 719 (quoting Herrmann v. Newark Morning Ledger Co., 138 A.2d 61, 72 (N.J. Super. Ct. App. Div. 1958)). He concludes: "Defamation law understands itself as regulating a specific class of communications which have the 'general tendency' to cause reputational harm; it does not simply provide compensation for financial or associational losses resulting from untrue communications generally." Id. If Post's assertion is accurate, it seems appropriate to ask why damages need ever been proved as an element of the plaintiff's case.

51. KeETON, supra note $49, \S 112$, at 794 . Standing alone, personal injuries such as hurt feelings are not subject to redress. Post specifically notes that, while "individuals may attach importance to the way others regard them, a decline in this regard resulting merely in hurt feelings should not be the subject of redress." Post, supra note 32, at 695. As the prolific commentator Thomas Starkie wrote a century and a half ago, "mere injury to feelings without actual deterioration of person or property cannot form an independent and substantive ground for proceeding." Id. at 695 (quoting STARKIE ON SLANDER, supra note 34). See also Anderson, Reputation, supra note 7, at 759-64 (discussing the history and theory of recovery and nonrecovery of emotional distress damages in defamation law).

This rule arguably reflects a bias that feminist scholars argue is widespread in tort law: the category of physical harm is valued over that of emotional harm. Chamallas \& Kerber, supra note 25, at 816; Chamallas, supra note 25, at 525-26. Indeed, in the late twentieth century, the U.S. Supreme Court recognized that emotional injuries alone may constitute a defamation damages award, even apart from proof of injury to reputation. Time, Inc. v. Firestone, 424 U.S. 448 (1976). There, being defamed by a statement in the publication made the plaintiff anxious and concerned. She also said she feared her young son would be affected by the falsehood when he was older.

Damages awards may even include projected future damages of these same types. Punitive or exemplary, as well as nominal damages, may also be awarded in defamation cases. See generally, KEETON, supra note $49, \S 116 \mathrm{~A}$, at $842-47$ (discussing the various categories of damages associated with defamation law).

52. "For the last century, it has been well settled that any words written and published throwing contumely on a person are actionable without proof of special damages." C.G. Addison, A Treatise on the LaW OF TORTS OR WRONGS AND Their Remedies 46-47 (William E. Godon et al. eds., 8th ed. 1906). 
defamation. ${ }^{53}$ With slanderous statements, on the other hand, the common law recognized only three categories of statements as receiving the benefit of this presumption of damages. They are statements that (1) undermine the plaintiff's competence in a way associated with his business or profession, ${ }^{54}(2)$ impute criminal behavior to the plaintiff, ${ }^{55}$ or (3) indicate that the plaintiff had a loathsome or contagious disease. ${ }^{56}$ Again, a fourth per se category, for statements impugning a woman's chastity, was recognized in different U.S. jurisdictions at different points throughout the nineteenth century. ${ }^{57}$ When slanderous statements did not fall into one of these categories, plaintiffs were required to establish special damages, meaning pecuniary or material loss. Once that pecuniary loss was established, damages associated with emotional distress, physical illness, and the like were permitted as parasitic to the reputational damage. ${ }^{58}$

Early U.S. law on sexual slander echoed the English traditions in which it was rooted. Because sexual slander was not actionable in English law courts, women in Medieval England began to bring such claims to ecclesiastical courts in the sixteenth and seventeenth centuries. ${ }^{59}$ While ecclesiastical courts could not award damages, they

53. Of course, much in the common law of defamation, including rules regarding damages, has been altered since the Supreme Court decisions in New York Times v. Sullivan, 376 U.S. 254 (1964) and Gertz v. Robert Welch, Inc., 418 U.S. 323 (1974). See generally Rodney A. Smolla, Dun \& Bradstreet, Hepps and Liberty Lobby: A New Analytic Primer on the Future Course of Defamation, 75 GEO. L.J. 1519 (1987) (summarizing constitutional changes to defamation law following germinal Supreme Court cases in the 1980s). A discussion of those many and complex changes is beyond the scope of this Article, which focuses on the common law of defarnation long before its constitutional implications were identified. Suffice to say here that the presumed damages rule associated with libel has been largely, if not completely abrogated, in the constitutional era. KEETON, supra note $49, \S 112$, at 796 . For an excellent argument for the abolition of presumed damages and the embrace of a rule requiring proof of actual damage to reputation, see Anderson, Reputation, supra note 7, at 749-64.

54. Male plaintiffs sometimes alleged that statements impugning their chastity undermined them in their trade or business. In one such English case, Ayre v. Craven, 2 Ad. \& E. 2, 111 Eng. Rep. 1 (K.B. 1834), the court denied that the case of a male physician charged with "incontinence" stated a case of slander per se because he did not establish "how the speaker connected the imputation with the professional conduct." Id. at 2 (commentary).

55. See, e.g., Tharp v. Nolan, 84 S.W. 1168 (Ky. 1905); Herzog v. Campbell, 66 N.W. 424 (Neb. 1896).

56. See, e.g., Elsas v. Browne, 68 Ga. 117 (1881); Moore v. Francis, 23 N.E. 1127, 1128 , 121 N.Y. 199, 203 (1890); Womack v. Circle, 70 Va. 192 (1877). Initially, this per se category referred only to venereal disease. McDonald v. Nugent, 98 N.W. 506 (Iowa 1904); Kaucher v. Binn, 29 Ohio St. 62 (1875). It sometimes also included leprosy, but not diseases such as smallpox. Simpson v. Press Publ'g Co., 67 N.Y.S. 401 (N.Y. Sup. Ct. 1900).

57. This is a relatively rare example of an expressly gendered double standard in tort law. See Chamallas, supra note 25 , at 521-22 (observing that few lawmakers would openly rely on gender differences to justify denying women's claims or discounting their injuries and that the "mechanisms that maintain the gendered hierarchies of value are more subtle" Id. at 521.). See also King, supra note 2, at 72-75, 81-90 (discussing different U.S. jurisdictions adoption, by judicial opinion or legislation, of this slander per se category).

58. KEETON, supra note $49, \S 112$, at 793-95.

59 See generally Kif Augustine-Adams, Defamed Women: Salve Deus Rex Judaeorum, 22 HARV. WOMEN's L.J. 207 (1999) (featuring a history of women's sexual slander claims before 
could order repentance and apology ${ }^{60}$ Sometimes sexual slander claims "crossed over" from ecclesiastical to law courts because the type of injury suffered made the claim cognizable in law. Thus, in Davis v. Gardiner, a law court accepted jurisdiction when a statement that the plaintiff had given birth to a child outside marriage caused her fiancé to break their engagement to marry. ${ }^{61}$ It was said there that " $[t]$ hough the words were a spiritual slander, yet the loss of marriage was temporal." 62 The distinction between claims brought before ecclesiastical courts and those brought before law courts was sometimes expressed as that between "moral slander" and "legal slander,"63 or that between the spiritual and the temporal. In effect, sexual slander was a variety of moral slander, but it could be converted to a legal slander, as illustrated in Davis v. Gardiner, by the pleading and proof of so-called temporal damages. ${ }^{64}$

ecclesiastical courts).

60. Martin Ingram, Church Courts, SeX and MaRRiage in EnGLand, 1570-1640, 292-94 (1987).

61.76 Eng. Rep. 897 (1593).

62. Id. at 16b. The editor of the case reports in which Davis is reported explained that words imputing "an offence cognizable in a Spiritual Court, may be punished in such a Court." Id. at $898 \mathrm{n}$.(A). A suit for spiritual defamation has three requirements: (1) it must "concern matter merely spiritual and determinable in the Ecclesiastical Court, as calling a man a heretic, adulterer . . . or a woman a whore"; (2) "[t]hat it concern matter merely spiritual only"; otherwise the "Ecclesiastical Judge shall not have cognizance of it" and (3) the plaintiff may not seek "damages or amends, but only the punishment of the sin ... and for costs." Id. The editor goes on to opine that "if actionable words are coupled with words which are a spiritual defamation," and a suit may not be instituted in the "Spiritual Court for the whole ... if it be suggested to the Court that a temporal damage has been received from words which are a spiritual defamation, a prohibition lies; for it would be vexatious to proceed in both Courts." Id.

63. King, supra note 2, at 70-71. This language was also sometimes reflected in U.S. cases, as in Buys $v$. Gillespie in which a New York judge wrote that "[t]here are many imputations against the moral character of a person which are not actionable." 2 Johns. 115, 116 (N.Y. Sup. Ct. 1807); see also Berry v. Carter, 4 Stew. \& P. 387, 390 (Ala. 1833) (referring to moral slander and legal slander); Coburn v. Harwood, Minor 93 (Ala. 1822) (in holding that adultery was not slander per se, the court wrote that it was "unquestionably a crime of the highest moral turpitude, 'the very mention of which is a disgrace to human nature: a crime not fit to be named amongst Christians," 'but that the "[s]tatutes of this state have taken no notice of it"); Pledger $v$. Hathcock, $1 \mathrm{Ga} .550$ (1846) (noting that in Great Britain, sexual slander is cognizable in the spiritual courts and not in the temporal courts); Elliot v. Ailsberry, $5 \mathrm{Ky}$. (2 Bibb) 473, 473 (1811) (discussing the fact that offenses against chastity were the subject of "ecclesiastical cognizance" in England); Terwilliger v. Wands, 17 N.Y. 54, 63-64 (1858) (distinguishing between law and morality); Wilson v. Goit, 17 N.Y. 442, 444-45 (1858) (noting that from a moral point of view, the defendant was liable for all consequences of his slander, but that from a legal standpoint, the action was solely for the vindication of an injured reputation); Young $v$. Miller, 3 Hill 21 (N.Y. Sup. Ct. 1842) (distinguishing between moral and legal slander in a case not involving chastity).

64. The Indiana Supreme Court in Dukes v. Clark, offered an extensive statement regarding the difference between temporal courts and spiritual courts. 2 Blackf. 20 (Ind. 1826). The court observed:

Where an action was brought for words, in calling the plaintiff heretic and one of the new learning, it was held clearly that it would not lie, being merely a spiritual matter; for if the defendant was disposed to justify and show in what respect the 
Having no ecclesiastical courts to take jurisdiction over cases in which women stated merely "spiritual" injuries, sexually slandered women in the United States had recourse only in courts of law. Further, consistent with these early English cases, they had recourse there only if they were able to show the "temporal" or pecuniary nature of their injuries. ${ }^{65}$ U.S. courts sometimes embraced the English terminology, noting that "spiritual" injuries were not sufficient to make a claim actionable in law. ${ }^{66}$ Whatever the terminology, U.S. courts of the era before sexual slander was recognized as slander per se embraced a parallel dichotomy between injuries that were deemed cognizable in defamation law and those that were not.

Eventual recognition of sexual slander as slander per se was highly significant as a practical matter because it freed the plaintiff from the burden of proving special damages as an element of her prima facie slander case. ${ }^{67}$ Because of the gravity with these categories of per se statements were viewed by society, their tangible impact on a

plaintiff was a heretic, the temporal Court could not judge of it; and it was not like where the court had cognizance of the principal matter, as where a man was called traitor, or felon. Again, if he had called him adulterer, this being a spiritual matter, an action would not lie for it. But Fitzherbert said, that where things were of a mixed nature, as where a man was said to keep a bawdy-house, he might elect whether he would have his action here or in the spiritual Court. 27 Hen. 8-14; Reeves' Eng Law. 385.

Id. at $21 \mathrm{n} .1$.

65. Professor David Anderson has explained that "special harm is the descendant of the temporal harm concept" used by common law courts to take jurisdiction in some slander cases from ecclesiastical courts. "When the common law judges discovered that there was more slander in the world than they had bargained for, they turned the harm requirement around and used it to screen out cases by holding that the plaintiff had failed to plead or prove the requisite kind of harm." Anderson, Reputation, supra note 7, at 759 (citing Van Vechten Veeder, The History and Theory of the Law of Defamation, 3 ColuM. L. REv. 546, 555-58 (1903)).

66. One such case is Buys v. Gillespie, the earliest sexual slander case in New York. 2 Johns. 115 (N.Y. Sup. Ct. 1807). In that case, the attorneys made arguments referring to the lack of ecclesiastical courts in the United States. The defense attorney noted that "the spiritual courts alone take cognizance of such causes" in England. Id. The attorney for the plaintiffs conceded that point, but then argued that, because in New York there are no ecclesiastical courts "who act pro salute animae, and for the reformation of morals ... [A]nd the same reason does not exist here why the civil courts should not lend their aid to punish such offences." Id. at 115-16. See also supra note 63 (discussing other U.S. cases).

The opinion in the case did not specifically mention the absence of ecclesiastical courts, but it did discuss differences in English and U.S. divorce law. These differences meant that the plaintiff had to plead specifically a loss of dower in order that her claim for slander based on an allegation of adultery could be recognized. Without pleading and proof that her husband was "seised of any estate whereof the wife could be endowed," there was no proof that the charge of adultery had caused her to lose anything of monetary value. Id. at 118. By contrast, the court noted, under English law, adultery resulted in qualified divorce and the wife remained entitled to dower, and to alimony in the spiritual courts. Id. at 117-18.

67. This rule is typically justified by noting that "damage to reputation is recurringly difficult to prove and that requiring actual proof would repeatedly destroy any chance for adequate compensation." Gertz v. Robert Welch, Inc. 418 U.S. 323, 394 (1974), quoted in Post, supra note 32, at 697-98. This is no longer the law in the constitutional era of defamation, when damages are no longer presumed in any categories of cases. 
plaintiff's reputation was presumed. ${ }^{68}$ In the case of women suing when their reputation for chastity was impugned, ultimate recognition of the fourth slander per se rule meant that they did not have to prove loss of marital prospects or other types of special damages that might be seen as having a pecuniary character.

Prior to their judicial or legislative recognition that a statement impugning a woman's chastity constituted a dedicated slander per se category, some jurisdictions "bridged the gap" between sexual slander and then-existing slander per se categories by fitting the offending statement into one of those existing categories. ${ }^{69}$ For example, fornication, adultery, and prostitution gave rise to criminal liability in a number of states. Many of these jurisdictions therefore treated sexual slander, which generally imputed one of these crimes to the plaintiff, as slander per se on that basis. ${ }^{70}$ Some states required that the crime involve "moral turpitude" in order to constitute slander per se, and states varied with regard to whether certain crimes based on sexual misconduct satisfied this requirement. ${ }^{71}$ Some jurisdictions required the crime to be punishable by imprisonment in order for it to fall within the "favored" per se category. An oft-cited New York case embraced the rule that a statement is slander per se if it "will subject the party charged to an indictment for a crime involving moral turpitude, or subject him to an infamous punishment."

68. For an excellent critique of the practice of presuming damages in defamation law, see Anderson, Reputation, supra note 7, at 749-56. Professor Robert Post has also discussed the theoretical inconsistency between the doctrine of presumed damages and the concept of reputation as property. See Post, supra note 32, at 697.

69. See generally Pollard v. Lyon, 91 U.S. 225, 227 (1875) (collecting and discussing the approaches of different jurisdictions to this question of when a statement imputing lack of chastity gives rise to a criminal offense of the type that makes the statement slander per se).

70. See, e.g., Posnett v. Marble, 20 A. 813, 816 (Vt. 1890) ("charge of keeping a house of ill fame" was actionable per se because keeping "'a house of ill fame resorted to for the purpose of prostitution or lewdness"' was a statutory offense; court said that because punishment for offense was corporal, even though imprisonment was in a house of correction rather than in the state prison, because the crime involved "moral turpitude" and subjected the offender to imprisonment, the words were actionable); Miles v. Oldfield, 4 Yeates $423,423(\mathrm{~Pa}$. 1807) (charge that plaintiff was a vagrant was actionable per se because it subjected the offender to an "imprisonment at hard labor" for a term not longer than one month). By the same token, in jurisdictions in which unchaste behavior did not constitute a criminal offense, it was not deemed slander per se. Pollard, 91 U.S. at 228 (applying the law of the District of Columbia, where the crime of fornication had recently been repealed, even though the court acknowledged that "offences of this kind involve moral turpitude"). But see Hoar v. Ward, 47 Vt. 657 (1875) (calling the female plaintiff's children bastards did not, with sufficient certainty, impute a crime to the mother; thus, the statement was not actionable per se).

71. See, e.g., Andres v. Koppenhaefer, 3 Serg. \& Rawle 255, 258 (Pa. 1817) (words imputing the commission of an infamous offense are actionable per se; crime must be one that implies "moral turpitude"); Zeliff v. Jennings, 61 Tex. 458, 466 (1884) (words are actionable per se if they would subject the plaintiff to a punishment, "though not such as is known in the books, technically, as an ignominious punishment, if the accusation be such as to bring disgrace on the person ... which impute to the person ... a moral turpitude, which would exclude him from association with respectable persons").

72. Brooker v. Coffin, 5 Johns. 188, 191 (N.Y. Sup. Ct. 1809), discussed in King, supra note 2 , at 82-83. In holding that a statement charging a woman with being a common prostitute was not slander per se, the court noted that the same punishment ("commitment . . . to the bridewell 
held in 1809 that prostitution was not such a crime, the same court in 1816 held that an allegation of "keeping a bawdy house" was slander per se because doing so is a common nuisance and a crime "evidently involving moral turpitude." 73

Other states did not impose the "moral turpitude" or "punishable by imprisonment" requirement. In those and other jurisdictions, any crime sufficed. In Frisbee $v$. Fowler, ${ }^{74}$ for example, the Connecticut Court of Errors wrote:

But as by the laws of this state, the breach of chastity, in every form-from adultery to mere lascivious carriage - is punishable by statute, the consequence has been, that these charges have become words actionable in themselves. This point has been repeatedly decided, and may be considered to be settled law in this state. $^{75}$

Similarly, courts sometimes linked sexual slander with the long-established per se category regarding contagious or loathsome disease. When the offending statement charged a female plaintiff with having a venereal disease, for example, she often was not required to prove special damages because the statement fell neatly into an existing per se category, regardless of the fact that it also impugned her chastity. ${ }^{76}$

or House of Correction, to be kept at hard labor for a period not exceeding 60 days") applied to prostitutes, who were characterized in law as "disorderly persons," as applied to those "pretending to have skill in physiognomy, palmistry, or pretending to tell fortunes." Id. The court's point was that because these other offenses were not crimes involving moral turpitude, neither was prostitution. Id. The U.S. Supreme Court in Pollard v. Lyon cited Brooker v. Coffin with approval for the proposition that the per se rule applied to any offense which was criminally indictable, although not technically ignominious, if it involved moral turpitude and would affect social standing. Pollard, 91 U.S. at 234 (collecting cases and discussing the approaches of the different U.S. jurisdictions).

One court read Brooker to deem as slander per se charges of actions that would exclude the person from the "favor and countenance of all moral persons," as distinct from all persons generally. Dial v. Holter, 6 Ohio St. 228, 242 (1856), discussed supra note 46.

73. Martin v. Stillwell, 13 Johns. 275 (N.Y. Sup. Ct. 1816). Along those lines, in Buys v. Gillespie, the court wrote: "There are many imputations against the moral character of a person which are not actionable; but if any temporal loss or damage follow, if the law attaches any loss or disability to the crime or act charged, the words become actionable." 2 Johns. 115,116 (N.Y. Sup. Ct. 1807).

74. 2 Conn. 707 (1818).

75. Id. at 708. In the omitted footnote, the court wrote:

From the earliest period of our government, adultery has been, by statute, an indictable offence, and subject to severe punishment. It was, for some time, a capital crime; the punishment was then altered to whipping, burning on the forehead with the letter $A$., and wearing a halter; and lastly, by the act of May Session 1816, it was altered to imprisonment - the man in new-gate, the woman in common gaol,--from two to five years. Incest and polygamy are crimes punishable with equal severity. Fornication and lascivious carriage expose the offenders to corporeal punishment; which, it ought to be remarked, however, is seldom, if ever, inflicted.

Id. at n.a.

76. See, e.g., Williams v. Holdredge, 22 Barb. 396 (N.Y. Gen. Term 1854) (saying of a married woman that she has "the clap" or "the pox" is actionable per se, without proof of special 
While nineteenth-century chastity cases were relatively few in number compared to the many suits brought by male plaintiffs, statements about sexual propriety nevertheless gave rise to the vast majority of defamation cases brought by female plaintiffs in these jurisdictions. ${ }^{77}$ Indeed, women of this era very rarely sued in defamation based on statements that injured their reputations in any regard other than that related to chastity. ${ }^{78}$ Thus, there is a rich body of judicial decisions to mine for information about how nineteenth-century courts perceived and handled injury from sexual slander.

The cases considered below were litigated prior to the embrace of this fourth, woman-specific slander per se category, and they are not cases where courts "bridged the gap" to classify the statement within one of the existing per se categories. Rather, they are cases where courts were considering the sufficiency of the special damages pleaded, in order that the court could view the claim as cognizable in law. Many of the sexual slander cases discussed are from New York, because it was one of the last states to designate statements impugning a women's chastity sexual slander as slander per se, doing so in $1871 .^{79}$ As a consequence, New York courts were considering what constituted "special damages" in the context of these claims for six to seven decades before the New York legislature acted. Also discussed is the handful of cases from other jurisdictions that litigated this issue: Texas, Vermont, and Maryland. Those cases usually arose because the law in those states made sexual slander of unmarried women actionable per se, but did not confer this benefit on married women. Slander claims brought by those women who did not enjoy the per se presumption of damages forced these courts to grapple with the special damages questions, just as New York courts were doing. ${ }^{80}$

damages, because it falls within slander per se category regarding infectious disease).

77. King, supra note 2, at 73-74 (noting, for example, that New York appellate courts heard twenty-four sexual slander cases between 1807 and 1880 , and that seventeen of these were initiated by female plaintiffs and that "illicit sexual intercourse" accounted for most of the defamatory remarks).

78. Diane Borden, Patterns of Harm: An Analysis of Gender and Defamation, 2 CoMM. L. \& PoL'Y 105, 133-34 (1997). In this study, Borden notes that in the late nineteenth century, women tended to sue in defamation "based on their private-sphere social rules, culturally coded in terms of their sexuality (wives, mothers, housekeepers)" and that the law reinforced these "uni-dimensional cultural assumptions about women." Id. Of the fifty-one defamation actions brought by female plaintiffs based on allegations of immorality in the late nineteenth century, "almost two-thirds (32) involved want of chastity and adultery; six others involved disorderly house, five involved fornication, incest or rape, four involved prostitution, two involved immorality in general, one involved abortion and one involved bigamy." Id. at 125.

Even in modern times, only about eleven percent of defamation plaintiffs are women. Borden, Gender and Defamation, supra note 3, at 98 (citing RANDALl P. BEZANSON ET AL., LIBEL LAW AND THE PRESS 7 (1987)). Women are still more likely to win their defamation suits if they are suing on the basis of a statement that impugns their chastity than if they are suing on the basis of another type of statement, such as one injurious to occupational status. Borden, Gender and Defamation, supra note 3, at 98-99.

79. 1871 N.Y. Laws, c 219, discussed in King, supra note 2, at n.163 and accompanying text. The statute also empowered married women to sue in their own names and to retain any damages awards as their own.

80. See, e.g., Shafer v. Ahalt, 48 Md. 171 (1878), discussed infra notes 188-92; McQueen v. 
The denial of recovery to sexually slandered women of this era was not the result of any overt misogyny or any facial hostility toward the claimants as a class. Indeed, as already noted, courts appeared highly sympathetic-if also highly paternalistic ${ }^{81}$ - to these plaintiffs, often waxing poetic about female virtue and the need to protect it. ${ }^{82} \mathrm{An}$ Iowa court, for example, wrote in 1844 :

The reputation of a female for chastity, by the common consent of mankind, is regarded with a peculiar jealousy. The condition of women is, therefore, as to this virtue, such that if words such as are here laid were believed she would be excluded from society, and set aside as infamous in the common sense of the term. $^{83}$

An Iowa judge, for example, noting that in other jurisdictions sexual slander is not slander per se, wrote that if he had to follow that rule, he would be embracing a rule that society "shrinks from with a repugnance bordering upon horror." ${ }^{, 84}$ A Texas judge referred to the rule that sexual slander was not slander per se as a "blot upon the common law" and a "stigma upon our jurisprudence." 85 One court called it "an outlawed rule of negation whose sole function has always been to thwart natural justice in one of the dearest and tenderest of human interests." 1861 had called the rule "barbarous," and this language was endorsed in U.S. legal commentary of the time. ${ }^{87}$

In spite of their expressed sympathy for these plaintiffs, however, judges faced with

Fulgham, 27 Tex. 463 (1864), discussed infra notes 193-205; Underhill v. Welton, 32 Vt. 40 (1859), discussed infra notes 170-78.

81. An English judge in 1861 expressed a similar sentiment:

I may lament the unsatisfactory state of our law, according to which the imputation of words, however gross, on an occasion, however public, upon the chastity of a modest matron or a pure virgin, is not actionable without proof that it has actually produced special temporal damage to her; but I am here only to declare the law $\ldots$

Lynch v. Knight, 11 Eng. Rep. 854, 861 (H.L. 1861).

One scholar has labeled these judges "judicial patriarchs" and observed that they took over the role of the family patriarch as the traditional patriarchal family declined. MICHAEL Grossberg, Governing tHe HeARTH: LAW AND THE FAmILY in NinEteENTH-CENTURY AmERICA 290 (1985). Another scholar has observed that such judicial offerings are more "judicial paternalism," as judges seem to have been motivated by paternalism, even as they produced patriarchal results. King, supra note 2, at n.13. He describes how judges became "moral guardians of their community's traditional values." Id. at 65 . He also argues that "paternalism played a role in both judicial and legislative efforts to insulate the family structure from the effects of social and economic change." $l d$. at 66.

82. See supra text accompanying notes 1-2, and infra notes 118-19

83. Cox v. Bunker, Morris 269, 270 (Iowa 1844). The statement at issue was, "Mrs. Bunker is a dirty, lying bitch and a whore." Id.

84. Dailey v. Reynolds, 4 Greene 354, 355 (Iowa 1854).

85. McQueen, 27 Tex. 463, 469 (1864).

86. Interstate Co. v. Garnett, 122 So. 373, 378 (Miss. 1929) (quoting Cooper v. Seaverns, 105 P. 509 (Kan. 1909)).

87. Current Topics, 2 ALBANY L.J. 309-10 (1870) (referring to Lynch, 11 Eng. Rep. at 861, discussed infra notes 108-17). 
the challenge of sexual slander claims did not eliminate the common law requirement of a pecuniary injury to constitute special damages. They were, nevertheless, sometimes creative in identifying the requisite pecuniary injury. In early cases, courts did so whenever they could conceive of the harm done as cognizable in the narrow marketplace in which a woman's reputation for chastity represented her value or currency, if you will. ${ }^{88}$

Although they expressed outrage at the rule of law, many judges, particularly those in New York, clearly perceived that their hands were tied with respect to changing it. ${ }^{89}$ One New York judge, frustrated at his inability to provide redress when the female plaintiff there was charged with "lewdness," wrote:

[I]t is very palpable that the presumption of damage is quite as strong [in this case] as in any case in which it is presumed ... [f]or instance, damage is presumed if one charges a clergyman with intemperance or profligacy, because they tend to his temporal damage. So a charge of dishonesty in a lawyer, bankruptcy in merchant, ignorance in a physician, and many other cases: but where a charge of want of chastity is made against a female, which has a tendency to destroy her character and prospects in life, no action lies unless she can prove special damage. The courts have long regretted that they had not authority to

88. Also evincing their sympathy for these sexually slandered women, courts rarely overturned significant damages awards to these plaintiffs. For example, in Moody v. Baker, 5 Cow. 351 (N.Y. Sup. Ct. 1826), the appellate court upheld an award of $\$ 1450$ to a woman whose fiance broke their marriage engagement as a result of the defendant's slanderous statements about her. There the court wrote, "The damages, although liberal, are not so extravagant" as to require overturning. "There are no grounds to believe the jury were influenced by passion, prejudice or partiality." Id. at 357 . In another case, where a defendant challenged a $\$ 500$ award as excessive, the court said that while the

amount allowed the plaintiff is certainly very liberal ... the rule is, that in actions for slander the court will not grant a new trial on the ground of excessive damages, unless the amount is so flagrantly outrageous and extravagant, as manifestly to shew that the jury acted corruptly, or under influence of passion, partiality, or prejudice.

Douglass v. Tousey, 2 Wend. 352, 356 (N.Y. Sup. Ct. 1829). The court concluded that the verdict in the case at hand did not warrant such an inference. Id. (offending words were "you are a thief, you stole my wife's dress"). But see Long v. Long, 4 Pa. 29 (1846) (trial court remitted to $\$ 2000$ a $\$ 3000$ jury award to a woman slandered by allegations she was unchaste). In one of the more colorful of the rare cases in which an award of damages was deemed excessive, the court in Beggarly v. Craft, said the award of $\$ 4250$ was excessive given defendant's poverty, as well as his lack of malice. Following a lengthy discussion of the evidence of the plaintiff's lessthan-spotless reputation, the court opined that even "were [the plaintiff] chaste as Dianaunsullied as the snowdrift-were her thoughts as pure of those of the Pilgrim devotee while imprinting a kiss upon his favorite saint-the damages would have been too large..." $31 \mathrm{Ga}$. 309,315 (1860). At least one court, then, did not see female chastity as being so valuable.

It is also interesting to compare these cases to one in which a male plaintiff was alleged to be a "whoring fellow." The plaintiff therein did not have to prove special damages because the court considered that the words charged him with a crime, as was the rule in Pennsylvania when women were charged with adultery. The jury awarded the plaintiff $\$ 5600$ in damages, but the trial court ordered a remittitur for $\$ 2700$. Walton v. Singleton, 7 Serg. \& Rawle 449 (Pa. 1821).

89. See King, supra note 2, at 90. 
adjudge differently; they have not the power, and legislatures have not the inclination to do justice to injured female innocence. ${ }^{90}$

In spite of believing they were bound by precedent requiring special damages, earlynineteenth-century judges nevertheless appeared predisposed to provide redress for these sympathetic plaintiffs. Just one example is the case in which refusal of a public house to serve meat and drink was seen as adequate harm, even though the court acknowledged that it was "trifling."

\section{GENDER AND INJURY}

I have already stated my overarching argument that the injuries seen as legally cognizable by nineteenth-century courts in sexual slander cases reflect values associated with men, property, and the marketplace. Because historically only men functioned in the public sphere, the realm of property, commerce, and financial matters, politics, and the commercial marketplace were associated with men. ${ }^{92}$ Women's presence was historically limited to the private or domestic sphere. Women, therefore, as well as their concerns, were largely ignored by the law. ${ }^{93}$ In the defamation context, this meant that courts recognized as valid and therefore worthy of redress, only pecuniary injuries. Furthermore, courts were able to see as pecuniary only those injuries that related to reputation as property. In order to identify a pecuniary character to women's injuries, courts often analogized women's domestic or private circumstances to the then almost exclusively male public sphere of commerce and work. ${ }^{94}$ These courts characterized injuries to relationships as pecuniary injuries, stretching to identify financial consequences of the damaged relationships. Indeed, they did so even as they ignored the character of these injuries as relational.

Professor Martha Chamallas has discussed gendered dichotomies in tort law, including those evident in the characterization of injuries. ${ }^{95}$ She argues that bias has crept into tort law through "reliance on implicit hierarchies of values and dichotomous thinking." Chamallas asserts that facially neutral legal categories that classify injuries, such as "physical harm" or "pecuniary loss," may reflect values that are

90. Bradt v. Towsley, 13 Wend. 253, 254 (N.Y. Sup. Ct. 1835).

91. See infra notes 130-33 and accompanying text (discussing Olmsted v. Miller, 1 Wend. 506, 508 (N.Y. Sup. Ct. 1828)).

92. A great deal has been written, of course, about the separate spheres represented by the public and the private. See, e.g., Linda K. Kerber, Separate Spheres, Female Worlds, Woman's Place: The Rhetoric of Women's History, 75 J. AM. Hist. 9 (1988); Linda K. Kerber et al., Beyond Roles, Beyond Spheres: Thinking about [sic] Gender in the Early Republic, 46 WM. \& MARY Q. 565 (1989); Nadine Taub \& Elizabeth M. Schneider, Women's Subordination and the Role of Law, in The Politics of LAW: A Progressive CritiQue 151 (David Kairys ed., 1990). One synonym for the public-private dichotomy is the market-family dichotomy.

93. Professor Chamallas, among others, has observed that the absence of law in women's lives has sometimes had a disparate impact upon them. Chamallas, supra note 25, at 511 .

94. See, e.g., Bradt, 13 Wend. 253 (N.Y. Sup. Ct. 1835); Hardin v. Harshfield, 12 S.W. 779 (Ky. 1890); Malone v. Stewart, 15 Ohio 319 (1846).

95. See Chamallas, supra note 25 , at 467.

96. Id. at 466. 
gendered. ${ }^{97}$ She also argues that the privileged place of these categories in law has a disparate impact on women. ${ }^{98}$ Chamallas articulates three broad pairings of tort injuries that are implicitly gendered: physical/emotional, property/relational, and economic/noneconomic. ${ }^{99}$ Chamallas acknowledges the dangers of using traditional gendered stereotypes as analytical tools, that is, associating women with matters emotional or relational. She nevertheless argues that the item in each pairing that is associated with masculine, that is, physical, property, or economic, is more valued in tort law than the one associated with the feminine. ${ }^{100}$ Thus, the law takes more seriously, is less skeptical of, and values more highly physical injuries, injuries to property, and economic injuries. ${ }^{101}$

Chamallas also argues that, in categorizing losses, the law considers the nature of a loss in relation to who is suffering it. ${ }^{102}$ As an example, Chamallas argues that tort law was slow to recognize the validity and significance of emotional distress injuries because these injuries are associated with women. ${ }^{103}$ Chamallas advances this argument primarily in relation to the historically disfavored torts of intentional and negligent infliction of emotional distress. ${ }^{104}$

This bias against emotional distress injuries was sometimes attributed to concerns that plaintiffs could easily fabricate such claims, which could not be objectively verified. ${ }^{105}$ Additionally, courts expressed skepticism that such injuries could be clearly traced to the harm-causing event. ${ }^{106}$ Finally, judges often blamed plaintiffs for their own weakness or idiosyncrasy in succumbing to such injuries. Courts suggested that such injuries-if they had in fact occurred-were more the fault of the weak plaintiff than the consequence of any wrongdoing by the defendant. ${ }^{107}$

Nineteenth-century judges showed similar biases in their frequent refusal to recognize the validity of certain injuries suffered by sexually slandered women. Indeed, one of the cases that is frequently cited by Chamallas and others who have studied the history of emotional distress injuries is an English sexual slander case from

97. Id. at 467. Chamallas also argues that these categories may be seen as racial; I do not build on that argument here.

98. Id. at 467.

99. Id. at 525-30.

100. Id. at $469,522-23$.

101. Interestingly, this value hierarchy is arguably reflected in the current debate over federal medical malpractice reform, which would place caps on jury awards for pain and suffering and other noneconomic injuries. See Sheryl Gay Stolberg, House Backs Limit on Malpractice Awards, N.Y. TimES, Mar. 14, 2003, at A24.

102. Chamallas, supra note 25, at 467 (discussing Lynch v. Knight, 11 Eng. Rep. 854 (H.L. 1861), and citing Nancy Levit, Ethereal Torts, 61 GeO. WASH. L. REV. 136, 140-46 (1992)).

103. Id. at 499; see also Chamallas \& Kerber, supra note 25, at 823.

104. See Chamallas \& Kerber, supra note 25, at 819-34, 851-58; Chamallas, supra note 25, at $491-99$.

105. Chamallas \& Kerber, supra note 25 , at 824-34.

106. Chamallas, supra note 25, at 493 (citing Bosley v. Andrews, 142 A.2d 263, 267 (Pa. 1958)).

107. Id. at 493-994. Chamallas observes that more recent decisions more often base their reluctance to recognize mental distress damages on so-called "slippery slope" concerns and on a desire not to impose disproportionate liability. Id. at 494. 
1861: Lynch v. Knight. ${ }^{108}$ The offending statement in Lynch charged the female plaintiff with immorality - though not outright adultery-calling her an "infamous wretch," expressing regret to her husband that he had married her, and admonishing him to keep an eye on her if a certain Dr. Casserly came around. ${ }^{109}$ Because the statement did not constitute slander per se, the plaintiff had to establish special damages. She argued that her husband believed the defendant's communication and that he therefore determined he "ought not any longer to live with [her] and in consequence thereof, [he] was induced to refuse, and did in fact refuse to live any longer with" her. ${ }^{110}$ Furthermore, she alleged she was sent back to her father's house in the country, "where she resided for a considerable time, separated from her husband." 111 The plaintiffs argued "that such separation was solely and entirely caused by and resulted from the acts of the Defendant as aforesaid" and that they had "sustained damage.", 12

While the slandered woman and her husband were both named plaintiffs in the case, the opinions of three different judges sometimes discussed their interests as if they were quite distinct. The Lord Chancellor opined that the husband's action in casting her out of the marital home, was not a "natural and probable consequence of the words spoken." 113 He noted that if the offending statement had charged the plaintiff with adultery, it might have been foreseeable that her husband would throw her out of the house. Considering the words actually spoken, however, he observed "they contain no charge of adultery, nor any imputation of any kind which, if true, would justify the act of the Plaintiff William, or would induce any reasonable man to do such an act." "114 The Lord Chancellor concluded that the "special damage relied upon arose ... from the precipitation or idiosyncracy of the Plaintiff William dismissing the Plaintiff Jane from his house when he was only cautioned not to let her mix in society. ..."115

108. 9 H.L.C. 577 , 11 Eng. Rep. 854 (H.L. 1861).

109. The offending communication included these words:

Any singularity of conduct which you may have observed in your wife must be attributed to a Dr. Casserly of Roscommon, as she was all but seduced by him ... I have no other object in view in telling you about her conduct, and in speaking to you as I have done, but your own welfare. She is an infamous wretch, and I am sorry that you had the misfortune to marry her; and if you had asked my advice on the subject, I would have advised you not to marry her.

Id. at 855 (opinion of Lord Chancellor).

110. Id. at 856.

111. Id.

112. Id.

113. Id. at 860 .

114. Id.

115. Id. at 861 . It is something of a relief to see that women were not the only plaintiffs who showed themselves to be idiosyncratic. See infra notes 188-207 and accompanying text, discussing women's characterization as peculiar, fragile, and having unusually sensitive temperaments.

Lord Brougham, largely agreeing with the Lord Chancellor, belabored the point, somewhat unconvincingly:

Here the words are only that she had shown herself false and deceptive, and that before marriage she had been, not seduced, but had been all but seduced, by Dr. Casserly. "All but seduced"-that excludes the actually having been seduced. I am 
Lord Cranworth agreed with the Lord Chancellor "that the natural result of the imputations would have been to lead the husband to watch his wife more carefully ... and to attempt, as far as possible, to reclaim her from the habits of deception and falsehood into which she was represented to have fallen before her marriage." 116 Thus, both he and the Lord Chancellor rested their denial of recovery on the absence of causation between the defendant's statement and the harm of which the plaintiff complained. The two judges agreed that the overreaction of the husband, rather than the slanderous statement by the defendant, was to blame for the injuries the wife had suffered.

Lord Wensleydale's opinion focused less on causation issues (i.e., what would be the natural and legal consequences of such a statement) and more on the nature of the wife's claim of damages. In particular, she had claimed as the requisite special damages that she had lost the society of her husband when he sent her away. Characterizing the wife's claim as one for loss of consortium, Lord Wensleydale wrote:

\begin{abstract}
Mental pain or anxiety the law cannot value, and does not pretend to redress, when the unlawful act complained of causes that alone; though where a material damage occurs, and is connected with it, it is impossible a jury, in estimating it, should altogether overlook the feelings of the party interested. The loss of such service of the wife, the husband, who alone has all the property of the married parties, may repair by hiring another servant; but the wife sustains only the loss of the comfort of her husband's society and affectionate attention, which the law cannot estimate or remedy. She does not lose her maintenance, which he is bound still to supply; and it cannot be presumed that the wrongful act complained of puts an end to the means of that support without an averment to that effect. ${ }^{17}$
\end{abstract}

clearly of opinion that these words in an ordinary case, and with ordinary men, would not have led to the consequence of the wife being turned out of the house, and sent home to her father. I am therefore of the opinion that a sufficient ground of action has not been stated ....

Id. See infra Part III.C, discussing causation problems arising in other sexual slander cases. Other courts saw a broken marital engagement as a natural consequence of a statement impugning a woman's chastity or social propriety. See, e.g., Hardin v. Harshfield, 12 S.W. 779 (Ky. 1890).

116. Lynch, 11 Eng. Rep. at 862 (Lord Cranworth).

117. Id. at 863. Lord Wensleydale had begun the passage by describing the real value of a wife's role as her husband's servant:

[T] he benefit which the husband has in the consortium of the wife, is of a different character from that which the wife has in the consortium of the husband. The relation of the husband to the wife is in most respects entirely dissimilar from that of the master to the servant, yet in one respect it has a similar character. The assistance of the wife in the conduct of the household of the husband, and in the education of his children, resembles the service of a hired domestic, tutor or governess; is of material value, capable of being estimated in money; and the loss of it may form the proper subject of an action, the amount of compensation varying with the position in society of the parties. This property is wanting in none. It is to the protection of such material interests that the law chiefly attends.

Id. At another point in the opinion, the court analogizes a woman's loss of her husband's 
Thus Lord Wensleydale saw no pecuniary character or consequence of the wife's injury; accordingly, he ruled that there were no special damages to sustain her lawsuit.

Professor Chamallas's arguments about the gendered character of tort injuries are manifest in these various opinions in Lynch v. Knight: a failure to recognize and take seriously emotional distress injuries, the privileging of pecuniary losses, a tendency to characterize injuries based on the gender of the sufferer, and a skepticism that injuries suffered by women were natural and proximate results of the wrong. Such judicial tendencies are similarly present in the sexual slander cases that are the focus of my analysis here.

\title{
III. CONCEPTIONS OF INJURY IN SEXUAL SLANDER CASES
}

\begin{abstract}
A female against whom a want of chastity is established is at once driven beyond the reach of every courtesy and charity of life, and almost beyond the portals of humanity. By common consent, such an imputation is everywhere treated as the deepest insult and vilest charge that could be given or inflicted upon the victim or her friends, and the bowie knife or the cord must wipe out the stain, and punish the offender.

$$
\text { Dailey v. Reynolds }(1854)^{118}
$$
\end{abstract}

The world is censorious, and a woman's or a maiden's reputation for modesty and chastity is an asset of inestimable value. Its loss renders her poor indeed.

Cooper v. Seaverns $(1909)^{119}$

The sexual slander cases brought prior to the recognition of the dedicated slander per se category are particularly interesting-and revealing-because in these cases courts were grappling with the precise nature or character of the injury for which they were considering giving redress. To determine if the slandered woman had stated a prima facie case, courts had to consider whether the injury pleaded constituted special damages. What courts appeared to do in these cases was look for injuries to these women's reputations as a form of property, injuries that might be said to have tangible financial consequences, because they undermined the plaintiff's "marketability" for marriage, ${ }^{120}$ interfered with her marriage by which she enjoyed financial security, ${ }^{121}$ or caused her a loss of gratuitous hospitality, with an attendant increase in living

company to that of parents' loss of a daughter's company after her seduction:

For instance, where a daughter is seduced, however deeply the feelings of the parent may be affected by the wicked act of the seducer, the law gives no redress, unless the daughter is also a servant, the loss of whose service is a material damage which a jury has to estimate; when juries estimate that, they usually cannot avoid considering the injured honour and wounded feelings of the parent.

Id.

118. 4 Greene 354, 355 (Iowa 1854).

119. 81 Kan. 267, 105 P. 509 (1909).

120. See, e.g., Hardin v. Harshfield, 12 S.W. 779 (Ky. 1890); Moody v. Baker, 5 Cow. 351, 1826 WL 1982, at *4 (N.Y. Sup. Ct. 1826); Linney v. Maton, 13 Tex. 449 (1855).

121. See, e.g., Beach v: Ranney, 2 Hill 309 (N.Y. Sup. Ct. 1842); Lynch, 11 Eng. Rep. 854. 
expenses. ${ }^{122}$ Courts sometimes identified such favored injuries, even when the facts pleaded revealed personal, dignitary injuries that had undermined the plaintiff's relationship. Indeed, as the quote above indicates, courts of this era frequently acknowledged that sexual slander made a woman a social pariah, excluding her from the "courtes[ies] and charit[ies] of life." ${ }^{233}$ Yet, even as they acknowledged that, courts sought some pecuniary perspective on that essentially relational and dignitary injury.

\section{A. Relational Injuries as Pecuniary Injuries}

Various judicial decisions from this period recognize the existence of special damages when a female plaintiff proved that the offending statement caused her a loss of "hospitality" or "society." 24 While such injuries appear at first blush to be to familial and social relationships-relational injuries implicating dignity and perhaps community standing - nineteenth-century courts often engaged in somewhat contorted analyses in order to characterize them as marketplace injuries. For example, when a slanderous statement about a woman's lack of chastity caused her engagement to be broken, courts sometimes drew an analogy to broken contracts in the commercial marketplace. ${ }^{125}$ In other cases, courts went even more out of their way to identify a

122. See, e.g., Olmsted v. Miller, 1 Wend. 506 (N.Y. Sup. Ct. 1828); Williams v. Hill, 19 Wend. 305 (N.Y. Sup. Ct. 1838).

123. Dailey, 4 Green at 355.

124. See, e.g., Moore v. Meagher, 1 Taunt. 39, 42, 127 Eng. Rep. 745, 746 (C.P. 1807); Williams, 19 Wend. at 305; see also Pollard v. Lyon, 91 U.S. 225, 237-38 (1875) (collecting cases).

Courts did not always see loss of society or community as constituting pecuniary harm. For example, in Roberts $v$. Roberts, the plaintiff alleged that the offending words had caused her to be kicked out of the sect of Protestant Dissenters to which she had belonged. The court said that her being "prevented from attending religious worship" was "no loss of a temporal nature." 122 Eng. Rep. 874, 876 (Q.B. 1864). One judge characterized her loss as "the merely nominal distinction of being able to call herself a member. ..." Id. Another characterized her "special damage" as being "of a nominal nature." Id. (Crompton, J.). The third concurred in the denial of the plaintiff's case, saying that "What is here alleged is no more than loss of the consortium vicinorum." Id.

125. Marriage was clearly a very important status issue for women of this time. See supra note 15. The extraordinary value of marriage is reflected in the cases of the time. In Moody $v$. Baker, the court compared marriage to any other contract, the breach of which would give rise to injury:

If, then, the principle recognized in Bird v. Randall would authorize a recovery, when there was a contract for service, upon which damages might be recovered, I think it will apply with greater force where there has been a contract of marriage, and performance of it refused in consequence of the slander of the defendant ... in a case of the specific execution of a contract to marry, its value does not depend on the ability of a person to pay damages. It is, indeed, a temporal loss, but of a character not capable of being wholly repaired by the payment of money-the only substitute the law has devised.

5 Cow. 351, 355-56 (N.Y. Sup. Ct. 1826). The court in that case upheld a jury verdict and judgment of $\$ 1450$ for the plaintiff. Id. at 352,357. Chief Justice Savage dissented, continuing the analogy to the commercial context, stating that "no action lies against a third person, who, by slanderous words, not actionable in themselves, induces the contractor to violate his 
pecuniary consequence to an essentially relational injury. Courts sometimes discussed commercial and marketplace concepts, even when these bore no apparent or direct relation to the very personal injury at stake. ${ }^{126}$ These U.S. courts often cited English cases in which analogies had been drawn, for example, between a clergyman who loses his "preferement" when charged with intemperance or an innkeeper who loses guests as a consequence of being charged with having a contagious disease, and the sexually slandered woman who loses her marital engagement. ${ }^{127}$ One Ohio court compared the injury suffered by a sexually slandered woman and a tradesman, scoffing at the common law's protection of the latter's reputation when injured by a "few dollars and cents," while refusing to recognize the "deepest wound" upon a young girl's feelings. ${ }^{128}$ A Kentucky court drew a similar analogy, writing:

To falsely and maliciously say of a physician, lawyer, or shoemaker that he is a quack, jackleg, or cobbler, entitled the person thus spoke of to damages commensurate with the injury that such language has done his profession or trade. The reason is much stronger for protecting defenseless and helpless women

contract." Id. at 361.

Other courts similarly considered broken marital engagements, when a consequence of sexual slander, to be sufficient special damages. See, e.g., Reston v. Pomfreict, Cro. Eliz. 640, 640, 78 Eng. Rep. 879 (Q.B. 1597). In Davis v. Gardiner, 4 Co. Rep. 16b, 17a, 76 Eng. Rep. 897,899 (Q.B. 1593), the court analogized the woman's situation to that of a clergyman charged with heresy or an innkeeper charged with having an infectious disease. Just as the clergyman who loses his "preferement" as a consequence or the innkeeper who loses guests as a consequence, the sexually slandered woman who loses her engagement states special damages that make her case actionable at law. Id. In Linney v. Maton, 13 Tex. 449, 454 (1855), the court stated in dicta that a broken engagement constitutes sufficient special damages. However, the plaintiff was not allowed to recover in that case because the offending words had not been heard by any third party when the defendant spoke them, and that plaintiff herself had repeated them, thereby herself causing the injury of which she complained. The court wrote:

No slanderous report had been put in circulation. No shade had been cast upon the young lady's reputation. That was as fair, and it seems, notwithstanding the publicity which those having charge of it have given to the quarrel, continues as fair as before. The words, if uttered, had been instantly retracted; no one else had heard them; and since their publication by the parties themselves no one has ever believed them or suffered them to influence their conduct towards the lady except the intended husband, whose conduct it was necessary should be influenced in order to sustain a suit for damages.

Id. at 455-56.

126. Contemporary scholars have made similar leaps. Most notably, Professor Martha Ertman has analogized marriage to commercial contract and argued that legal principles from the commercial arena should be applied in marriage. See, e.g., Martha M. Ertman, Commercializing Marriage: A Proposal for Valuing Women's Work Through Premarital Security Agreements, 77 TEX. L. REV. 17 (1998); Martha M. Ertman, Marriage as a Trade: Bridging the Private/Private Distinction, 36 HARV. C.R.-C.L. L. REv. 79 (2001); Martha M. Ertman, Reconstructing Marriage: An InterSEXional Approach, 75 DENV. U. L. REv. 1215 (1998).

127. See supra note 125, discussing Davis v. Gardiner, 4 Co. Rep. 16b, 17a, 76 Eng. Rep. 897, 899 (Q.B. 1593).

128. Malone v. Stewart, 15 Ohio 319, 321 (1846), discussed supra note 21. 
against false and malicious imputations, that tend to humiliate and degrade them in society. ${ }^{129}$

Special damages were recognized in one case, Olmsted $v$. Miller, on the basis that the plaintiff, having been charged in the offending statement with lewdness, was subsequently denied "meat and drink" at a public house, and that "a person refused to take the plaintiff into his family to reside by reason of the slanderous words." ${ }^{130}$ While

129. Hardin v. Harshfield, 12 S.W. 779 (Ky. 1890).

130. 1 Wend. 506 (N.Y. Sup. Ct. 1828). The court wrote:

It appeared by the testimony of one witness, that after the speaking of the words, the plaintiff was at a public inn transacting business, and desired dinner to be provided for her; that the landlord spoke to his wife, who refused to provide the dinner, saying, she would not have a woman of such a character in the house. Dinner, however, was provided by some member of the family, but the plaintiff was not permitted to come to the table with the family, which refusal was in consequence of the speaking of the words by the defendant. Another witness testified, that he had agreed to take the plaintiff into his family to reside with him; but that in consequence of the reports in relation to her, he had refused to permit her to become an inmate of his house, until she cleared up her character by commencing a suit for the slanders uttered against her. It appeared probable, however, that this conversation took place previous to the speaking of the words proved on the trial.

Id. at 507 (emphasis added). This last sentence alludes to a causation issue; that is, whether the slander caused her to be ostracized or whether there was another cause, such as the actions underlying the offending statement. Apparently because of this causation issue, the plaintiff's verdict and $\$ 500$ award were reversed. The court wrote: "On the whole, I am constrained to say, that the plaintiff in the court below did not prove the words laid in her declaration, and, therefore, ought not to have recovered." Id. at 507, 510.

In a somewhat analogous case, a male plaintiff was called a "pimp," a "loafer," and said not to understand his business or to be capable of supporting his wife. In addition, the defendant made various defamatory statements about the plaintiff's wife, including that "She frequently visited me and asked for five dollars. I used his wife and had connection with her, as she had nothing to wear. ... I have placed spires on the street corners to warn customers not to go into his place." Flatow v. Von Bremsen, 11 N.Y.S. 680 (N.Y. City Ct. 1890). The court held that the slander was not actionable per se, and that the plaintiff had not proved special damages by his averment that "divers persons have refused to associate or transact any business with this plaintiff, and this plaintiff was thereby deprived of the benefits which would accrue to him from such association and business as aforesaid, to his damage in the sum of one thousand dollars." Id. Citing Olmsted v. Miller, Williams v. Hill, and Beach v. Ranney, the court did not explain why the loss of business was insufficient special damage, whereas loss of hospitality in the other cases had been.

Erwin v. Dezell is another interesting case in which a male plaintiff was unable to establish special damages. 19 N.Y.S. 784 (N.Y. Gen. Term 1892). There, the male plaintiff was said to "have been arrested for bastardy and of having paid $\$ 100$ to settle it." He alleged that as a consequence of the slander:

speculators and others who buy and deal in livestock and other farm produce have refused, and still refuse, to purchase plaintiff's live stock and other farm produce, by reason of the circulation and uttering of said false, scandalous, and defamatory words above set forth, to plaintiff's great loss and damage. Plaintiff further alleges, upon his information and belief, that his neighbors and acquaintances, and those 
the Olmsted plaintiff ultimately lost because the court did not believe her special damages were a consequence of the offending statement, the court's dictum regarding special damages is interesting. The Olmsted court concluded that the plaintiff's injuries were pecuniary, but did not specify how or why they reached that conclusion. The court summarized that the "plaintiff was refused civil treatment at a public house" and "refused the hospitality and protection of a friend."131 Olmsted relied on the germinal English case, Moore v. Meagher, which had identified a pecuniary character to a similar type of loss. ${ }^{132}$ The Moore plaintiff had averred that, by reason of similar charges, she had lost the "benefit of the society and hospitality of friends who had previously entertained her gratuitously,"133 which was valued at $£ 100$. While the Olmsted plaintiff apparently rode the coattails of that thinking, unlike the Moore court, the Olmsted court did not specify how the injury was pecuniary.

Williams v. Hill ${ }^{134}$ is another example of a New York court identifying the requisite

who have heretofore furnished him employment and purchased his farm products, now refuse so to do, as they before the uttering and speaking of said false and defamatory words above set forth by said defendant had done, and otherwise would have continued to have done, whereby the said plaintiff hath lost all those valuable benefits and advantages, being to him of great value, to wit, the sum of three thousand dollars, and hath been and is greatly impoverished, and all his friends and business acquaintances have wholly withdrawn their friendship and acquaintance, to plaintiff's damage of three thousand dollars.

[I]n consequence of these defamatory words, the plaintiff has been subjected to litigations which would not have been begun against him; has been unable to sell property; but in no case are the names or specifications given from which such a presumption may arise. The words charged are not spoken of the plaintiff in regard to his vocation in life, and the complaint does not state what that vocation is. It may be fairly inferred that such a charge would, if credited at all, result in injury to the reputation of any person; but this does not give a right of action. Such words fall in the class of cases which are not actionable, and as to the utterance of which a man must rely upon the good name and repute which he has earned by his life among his neighbors, and which serves him in good stead on such occasions. The law cannot take cognizance of every malicious scandal which is uttered by one against his neighbor.

Id. at 784 . With respect to the special damages alleged, the court rather summarily concluded that "[t]he averments of the complaint" were not sufficient to avoid demurrer. Langdon v. Shearer, 60 N.Y.S. 193 (N.Y. App. Div. 1899) (insufficient for male plaintiff, seeking to establish special damages, to state only that he had been "injured in his business financially" when he had not also stated how he was injured).

131. Olmsted, 1 Wend. at 510.

132. Moore v. Meagher, 1 Taunt. 39, 127 Eng. Rep. 745 (C.P. 1807) (discussed supra notes 13 and accompanying text), cited in Olmsted v. Miller, 1 Wend. 506 (N.Y. Sup. Ct. 1828) (discussed supra notes 13 and accompanying text).

133. Bradt v. Towsley, 13 Wend. 253, 254 (N.Y. Sup. Ct. 1835) (summarizing Moore). In Moore, the plaintiff had specifically pleaded that she had been deprived of $£ 100$ each year, the cost of the "valuable benefits and advantages" lost as a consequence of the slander. Moore, 1 Taunt. at 40, 127 Eng. Rep. at 745.

134. 19 Wend. 305, 306 (N.Y. Sup. Ct. 1838). In that case, the "words were proved importing direct criminal connection between the plaintiff and a man who visited her in the character of a suitor." 
special damages in injured relationships. The Williams plaintiff alleged "that certain individuals ... refused to hold intercourse and discourse with her, and to receive her into their houses, as before the speaking of the slanderous words they had been accustomed to do."1.35 The pecuniary nature of the harm was not apparent, and it is not clear from the case report how the plaintiff pleaded the pecuniary nature of the harm alleged. Indeed, all of the harms discussed appeared purely relational, as the plaintiff's extended family also turned her away from their home:

[An] uncle ... testified that the plaintiff had been in the habit of visiting his family, consisting of his wife and daughters, and was considered a welcome visitor; that after he heard the charges made against her by the defendant, he told her she must not come to his house any more till she cleared up her character; that she then left and had not been at his house since on a visit; that she called a few times afterwards on errands, when he requested her to keep away. ${ }^{136}$

Even though the uncle went on to testify that he never believed the report against the plaintiff, ${ }^{137}$ the court reiterated the rule: "The very decision was that the plaintiff being cut off from the hospitality of her friends, is such legal damage as will sustain an action . . . ."138 As in Olmsted, the pecuniary character of the injury was never specified, but the jury verdict and $\$ 2000$ award were upheld on appeal. ${ }^{139}$

\section{B. Emotional Injuries and Their Pecuniary Consequences}

A few early New York decisions identified pecuniary harm in injuries other than damaged or lost relationships, but this practice was quickly reversed. In Bradt $v$.

135. Id. at 305 .

136. Id.

137. Interestingly, the court here was not troubled by the possible causation problem raised by the uncle's admission. While his statement implied that he shunned his niece, not because he believed the statement that she was unchaste, but because he felt community pressure to distance himself from her because others in the community believed it, and he feared the consequences to himself of continuing to associate with her. Later courts were much more attuned to causation issues. See infra Part III.C.

138. Williams, 19 Wend. at 305 (citing Moore v. Meagher, 1 Taunt. 39, 127 Eng. Rep. 745 (C.P. 1807); STARKIE ON SLANDER, supra note 34, at 266). See also Bassell v. Elmore, 48 N.Y. 561 (1872) (special damages established when uncle of slandered plaintiff, with whom she previously resided, "discarded her from his family, and refused her a home on account of these aspersions").

139. The relaxed attitude of the Olmsted and Williams courts with respect to identifying pecuniary loss seems akin to the relaxed approach of nineteenth-century courts considering seduction cases. In seduction actions, the plaintiffs were initially required to show loss of their daughter's services. Although this requirement was eliminated by most jurisdictions in the late nineteenth and early twentieth centuries, one commentator has observed that the "requirement had always been something of a fiction in practice." Larson, supra note 15, at 385-86 n.43. Larson quotes Ball v. Bruce, 21 Ill. 161, 162 (1859), where the court observed that "slight evidence" of a woman's services was sufficient, including such reacts as "making tea, mending clothes, or other such like acts." In the same way, courts in sexual slander cases manipulated the pecuniary harm requirement, while also minimizing it by requiring only a "trifling" harm. 
Towsley, ${ }^{140}$ the New York court was uncharacteristically lax in its analysis of the type of injury pleaded, uncritically concluding that emotional distress and its consequences constituted special damages. The plaintiff, who was slandered by the defendant's statement that she was a prostitute, alleged an array of damages. She averred that her reputation was injured and that she was "brought into public scandal, infamy and disgrace." 141 As a consequence, she had become

sad and dejected in mind, and enervated, enfeebled and languid in body, for a long space of time, to wit, for the space of six months, during all which time she suffered and underwent great pain and anguish, and was hindered and prevented from transacting her necessary affairs and business. ${ }^{142}$

The court upheld the jury verdict and $\$ 5000$ award. ${ }^{143}$

In doing so, the court analogized the facts of the case to those of a "clergyman [charged] with intemperance or profligacy ... dishonesty in a lawyer, bankruptcy in a merchant, ignorance in a physician, and many other cases." 144 Completing the marketplace metaphor, the court observed that sexual slander "has a tendency to destroy [a woman's] charactar [sic] and prospects in life." ${ }^{145}$ The court also lamented that the plaintiff had no action absent proof of special damages. In going on to find special damages in that case, the court also relied on Moore v. Meagher ${ }^{146}$ and Olmsted v. Miller, ${ }^{147}$ both of which had involved claims of special damages based on the impact of the offending words on the plaintiffs' relationships, rather than on emotional distress and attendant physical infirmity. Without acknowledging this distinction, the Bradt court stated that even though "words charging a female with lewdness are not actionable, . . it is very palpable that the presumption of damage is quite as strong as in any case in which it is presumed." 148 The implication of this last line is that statements impugning a woman's chastity are so surely damaging that they are virtually slander per se. The Bradt court might well have relied on the plaintiff's allegation that her emotional upset had "prevented [her] from transacting her necessary affairs and business." 149 However, in concluding the injury was pecuniary, the court did not expressly indicate such reliance, or place any particular emphasis on this language.

Later New York decisions backed off Bradt, however. ${ }^{150}$ Only one New York court

140. 13 Wend. 253 (N.Y. Sup. Ct. 1835).

141. Id. at 253.

142. Id. at 253-54.

143. Id. at 254 . This is one of the larger damages awards made to a sexually slandered woman in the nineteenth century. Adjusted for inflation, $\$ 5,000$ in 1835 would be $\$ 85,156$ in 2001. See The Inflation Calculator, at http://www.westegg.com/inflation (last modified June 11, 2000).

144. Bradt, 13 Wend. at 254.

145. Id.

146. 1 Taunt. 39, 42, 127 Eng. Rep. 745 (Ex. Ch. 1807).

147. 1 Wend. 506 (N.Y. Sup. Ct. 1828).

148. Bradt, 13 Wend. at 254 (emphasis in original). It seems the court was suggesting that damages should be "presumed," as that word is used in common parlance, rather than as a term of art.

149. Id. at 253-54.

150. See infra notes 221-35 and accompanying text (discussing Beach v. Ranney and others). 
subsequently adjudged emotional injury to constitute special damages, and there, in Fuller v. Fenner, ${ }^{151}$ the woman's circumstances made it easier to identify a pecuniary character to the harm she suffered. A single woman who worked as a "tailoress," Ms. Fuller was defamed in what the court called an "exceedingly gross and cruel character." 152 Indeed, the defamatory statement was apparently so beyond the pale that the court omitted the actual words from its opinion. ${ }^{153}$ The defendant catalogued to the plaintiff, in the presence of the plaintiff's sister and father, various acts of "criminal intercourse" that the plaintiff had allegedly committed with defendant himself. ${ }^{154}$ These acts, he said, had occurred in different places, and some had occurred in what the court characterized, without providing details, as "the most revolting circumstances." 155 The hurtful and damaging substance of the statements was aggravated by the manner in which they were made: the plaintiff's sister, who was also the defendant's wife, was present at their speaking; the children of the defendant and the plaintiff's sister were present as well.

The plaintiff alleged, as a consequence, severe emotional distress that prevented her from working for some time. She put on evidence that she was hardly able to walk home following the statement. Her father testified, "I returned home with the plaintiff. It [the slanderous charge] seemed to affect her pretty bad. She walked rather slow. She was not able to do much of anything for four or five days." ${ }^{156}$ In addition, the plaintiff's brother testified that she was unable to complete a coat she was making for him and that he had to purchase one instead. The brother testified that two days after the offending words were spoken, "[s]he was ill in bed, and sat up about one hour in the day, and seemed much agitated." 157 The court concluded " $[\mathrm{t}]$ hat she was sick, and lost the earnings of her trade during her illness, [which] is proved by evidence that is uncontradicted." 158 The court then considered whether this illness was the consequence of the words spoken, again deferring to the jury's judgment that it must have been the

In addition, the Vermont Supreme Court in 1859 relied on Bradt in finding, essentially, that plaintiff's "loss of time" was a pecuniary injury. See infra notes 170-78 and accompanying text (discussing Underhill v. Welton, 32 Vt. 40 (1859)).

151. 16 Barb. 333 (N.Y. Gen. Term 1853).

152. Id. at 335 .

153. This was not an uncommon phenomenon in sexual slander cases, as courts found themselves squeamish about reciting the slanderous words spoken, while also struggling to paraphrase them in the opinions. In one 1854 case, the Alabama Supreme Court wrote, "[t]he acts and words thus proved are much too gross and brutal to find a record in this opinion, and could only arise from a malice which would be satisfied with nothing short of the utter degradation of its victim." Ware v. Cartledge, 24 Ala. 622, 627 (Ala. 1854).

154. Id.

155. Id.

156. Id. (emphasis in original). The court did not quibble over causation, writing: "This was a natural and probable cause. There was an absence of any other cause, in the proof." Id. The court also noted that the jury obviously had not identified a causation problem; otherwise, they would have returned a contrary verdict. This acceptance of causation is in sharp contrast to many subsequent cases, which questioned the causal link between the slanderous statement and the distress the plaintiff suffered. See infra Part III.C.

157. Fuller, 16 Barb. at 335.

158. Id. at 336. 
cause and citing evidentiary support for that causal link. ${ }^{159}$ Finally, the court upheld the jury's $\$ 800$ award over the defendant's complaint that it was excessive.

In finding the plaintiff's loss to be a pecuniary one, the court noted that the plaintiff was a "tailoress by trade" and "dependent on her labor, for her support." 160 The court wrote:

Now granting that it is not enough, that the special damage arises out of distress of mind and pain of body, occasioned by physical illness produced by the speaking of the words, yet when that illness occasions an incapacity to labor, and thus deprives the plaintiff of the pecuniary gains to be derived therefrom, I know of no case that holds such damages to be insufficient to sustain the action. ${ }^{161}$

The court continued:

The natural effect of such a charge, so made, on the feelings of a female of the ordinary sensibilities of her sex, must have been of a very exciting and agitating character; which effect would naturally be followed, in a person of delicate health ... by a corresponding depression. ${ }^{162}$

The Fuller court cited Moore v. Meagher, ${ }^{163}$ Bradt v. Towsley, ${ }^{164}$ Olmsted v. Miller, ${ }^{165}$ and Williams $v$. Hill, ${ }^{166}$ summarily concluding that those cases are not in conflict with the legal principle, but that "on the contrary they affirm it."167 The Fuller court did not acknowledge that those cases articulated entirely different injuries-in particular, injuries with a genesis in and flowing from damaged relationships. In Fuller on the other hand, the injury had originated in the plaintiff's emotional upset. ${ }^{168}$ Subsequent New York opinions were much more skeptical of special damages claims that originated in the plaintiff's emotional distress injury, even when married women plaintiffs and husbands suing on their behalf alleged that pecuniary injuries flowed

159. See id. at 336. The court wrote:

We have already expressed the opinion that the nature of the charge, the rude and cruel manner in which it was made, the immediate effect upon the plaintiff, the reaction that took place on the way home from the defendant's house, all concur to show it very probable that the illness that immediately succeeded was the effect of these exciting events, upon an overwrought and feeble frame.

Id. But see Wilby v. Elston, 8 C.B. 142 (1849), 137 Eng. Rep. 462 (1913) (teacher alleged loss of pupils at her school as special damages, but court denied that this constituted special damages because of some doubt that the former was a consequence of the latter).

160. Fuller, 16 Barb. at 334.

161. Id. (emphasis added).

162. Id.

163. 1 Taunt. 39, 42, 127 Eng. Rep. 745 (Ex. Ch. 1807).

164. 13 Wend. 253 (N.Y. Sup. Ct. 1835).

165. 1 Wend. 506 (N.Y. Sup. Ct. 1828).

166. 19 Wend. 305 (N.Y. Sup. Ct. 1838).

167. Fuller, 16 Barb. at 335.

168. Courts over the years have occasionally permitted recovery in defamation law based solely on emotional upset, absent injury to reputation. See Modisette \& Adams v. Lorenze, 112 So. 397 (La. 1927). 
from the emotional upset. ${ }^{169}$

Courts in a few other states were as lax as the early New York courts about the special damages requirement for women suing for sexual slander, even when the core of the injury was emotional distress. In Underhill $v$. Welton, ${ }^{170}$ a Vermont court in 1859 required a single woman to establish "special and pecuniary loss or damage"171 because the charge that she was a whore was not actionable per se. ${ }^{172}$ The plaintiff alleged in the first count that "she was subjected to great distress in feeling, loss of time, and otherwise greatly injured" by the offending words. ${ }^{173}$ In the second count, she alleged that she "was also prevented and disabled from pursuing and following her accustomed duties and labors with the strength and health that she otherwise would have enjoyed." 174 Elsewhere, the court characterized her injury as a "loss of time and inability ... to perform her ordinary domestic and household duties." ${ }^{175}$ The court opined that "either of the counts sufficiently alleges a pecuniary damage." Bradt v. Towsley ${ }^{177}$ and characterizing it as similar to the case at hand, the Vermont court said that "allegation of loss of time ... has always been regarded as a good allegation of pecuniary loss." 178 Even for a plaintiff who was not financially responsible for herself, the court endorsed the old adage that "time is money."

Similarly, the Texas Supreme Court in the 1882 case of Ross v. Fitch ${ }^{179}$ affirmed that there was sufficient evidence to support a jury verdict for the husband and wife plaintiffs, who had to prove special damages based upon the defendant's statement

169. See infra Part III.C.

170. 32 Vt. 40 (1859).

171. Id. at 42 (emphasis added).

172. The statement would have been actionable per se, had she been charged with a criminal act such as "sexual connection with a married man, or a charge of unchaste conduct of a character that would amount to open and gross lewdness." $1 d$. at 41.

173. Id. at 42 . The court elsewhere characterized evidence of the plaintiff's injury as indicating that she was "greatly troubled in mind, and became very nervous, and did not appear well, nor look well, and sometimes waked up in the night and shed tears, and that this rendered her less capable of attending to her ordinary household affairs than she otherwise would have been." Id. at 41-42.

174. Id. at 42 .

175. Id.

176. Id.

177. See supra notes $140-49$ and accompanying text.

178. Underhill, $32 \mathrm{Vt}$. at 42 . The court went on to say that the "partial inability" to perform her labor, as alleged in the second count, would also be sufficient. For that proposition, the court cited Beach v. Ranney, discussed infra notes 221-35 and accompanying text, calling it a "sound and sensible decision." Underhill, $32 \mathrm{Vt}$. at 43.

In another Vermont case in which special damages did not have to be established because the statement was actionable per se, Wilcox v. Moon, 22 A. 80 (Vt. 1891), the court similarly failed to draw a bright line between pecuniary injuries and nonpecuniary injuries in the way in which New York courts had done. In Wilcox, the court said that the plaintiff had been "brought into public scandal, infamy, and disgrace, and greatly injured in her good name, and suffered great grief and mental anxiety, and been deprived of much sound sleep, and lost much valuable time, and been otherwise greatly injured." Id. at 81 .

179. 58 Tex. 148 (1882). 
imputing to Mrs. Fitch a "want of chastity." ${ }^{180}$ The plaintiffs alleged that they were poor and dependent upon their daily labor to earn a living. They said they had been refused "employment, and polite and civil treatment" because of the slander. ${ }^{181}$ They asserted that, as a consequence of the slander, a number of boarders left the Fitches' boarding house, and that Mrs. Fitch was planning to start a school, but that those parents who would have sent children to her school decided against it. Finally, Mrs. Fitch alleged that she was ill and not fully able "to perform her accustomed household labor." ${ }^{182}$ The defendant appealed from the verdict for the plaintiff and the award of $\$ 1000$, arguing in their amended pleading that the plaintiffs had not named specific persons who had withheld business or employment from the plaintiffs. The court nevertheless upheld the verdict and award, stating that the plaintiffs were not required to provide names of those who refused to employ them, nor of those who "refused them polite and civil treatment." 18.3 Reviewing the evidence, the court said that while it was "meager," it was nevertheless sufficient to sustain the verdict. ${ }^{184}$ Evidence of what might be considered typical pecuniary injuries, in particular the loss of custom at their boarding house and school, eliminated the need for the court to scrutinize the character of Mrs. Fitch's emotional distress injury. It may, nevertheless, be significant that the court did not dismiss as irrelevant Mrs. Fitch's allegations of illness and its impact on her performance of household duties.

As these cases illustrate, a few courts were able to see injuries that were, in their genesis, emotional distress injuries, as having pecuniary consequences. Such a leap from the emotional to the pecuniary, however, was dependent on the emotional upset causing the plaintiff to incur some out-of-pocket expenses. Indeed, these decisions might be seen as reflecting a quip from Moore v. Meagher, the 1807 English opinion in

180. Id. at 148 .

181. Id. at 149.

182. Id.

183. Id. at 151 . Similarly, they were not required to list the names of any boarders who left their boarding house, nor the names of those who refused to send their children to Mrs. Fitch's school. Id. The Texas court's relaxed standards on requirement of proof might be contrasted with a few New York cases at the turn of the twentieth century. See, e.g., Smid v. Bernard, 63 N.Y.S. 278 (N.Y. Sup. Ct. 1900) (requiring male plaintiff seeking to establish special damages to "give the names of those who have ceased to deal with him . . . or prov[e] that their so ceasing is due to the defendant's words" in order to avoid having claim dismissed); Erwin v. Dezell, 19 N.Y.S. 784 (N.Y. Gen. Term 1892) (male plaintiff's pleading that his neighbors no longer gratuitously supplied him farm products and that he is "greatly impoverished, and all his friends and business acquaintances have wholly withdrawn their friendship and acquaintance" insufficient special damages); Langdon v. Shearer, 60 N.Y.S. 193 (N.Y. App. Div. 1899) (insufficient for male plaintiff, seeking to establish special damages, to state only that he had been "injured in his business financially" when he had not also stated how he was injured)

184. Ross, 58 Tex. at 152. This decision is reminiscent of Hartley v. Herring, 8 T.R. 130, 101 Eng. Rep. 1305 (K.B. 1799), in which the court held that a clergyman charged with "incontinence" and seeking to establish special damages, did not have to provide the names of the congregants who had been responsible for dismissal from his post. The court wrote: "He has stated, that in consequence of the words spoken of by the defendant, he was removed from his office, and lost the emoluments of it, which, I think, is sufficient." Id. at 133. Compare the Ross court's deference to the jury's conclusion on the evidence to that of the McQueen court, discussed infra notes 193-205 and accompanying text. 
which the court identified special damages were a loss of hospitality: "If this action lies, no words are not actionable with the aid of an ingenious special pleader." ${ }^{185}$ In fact, the subsequent reversal of this trend, reflected primarily in New York decisions, disproved the proposition that ingenious pleading could always establish pecuniary loss. Later courts, especially in New York, were more hostile to emotional distress injuries, even when pecuniary consequences naturally flowed from them.

\section{Emotional Injuries as Nonpecuniary Injuries and Causation Challenges}

In sharp contrast with the successful plaintiffs in Bradt, Fuller, Underhill, and Ross, many other nineteenth-century courts did not view favorably the claims of sexually slandered plaintiffs. This was even so when the women averred that the slanderous statements about their chastity caused them great emotional upset as establishing special damages. Accordingly, their slander claims were not legally cognizable. As one commentator wrote, defamation law exists to compensate "temporal losses, not spiritual grievances, which cannot be estimated in money."186

Borrowing terms from English ecclesiastical courts, these U.S. courts generally explained that mere injury to the plaintiff's feelings, which were seen as "spiritual grievances," did not state an adequate basis for proceeding. ${ }^{187}$ One plaintiff, for example, alleged that a slanderous charge had made her

185. 127 Eng. Rep. 745, 746-47 (C.P. 1807).

186. STARKIE ON SLANDER, supra note 34, at 1. See also supra notes 61-64 and accompanying text (discussing this distinction between the temporal on one hand and the moral or spiritual on the other).

187. See supra notes 95-107 and accompanying text (discussing the bias against emotional injuries that has been observed by feminist scholars who see it is as a gendered phenomenon).

On the basis of the old English defamation case of Lynch v. Knight, 11 Eng. Rep. 854 (1861), and many other cases, Professor Martha Chamallas argues that "in a gendered world, injuries are socially constructed so that the gender of the person claiming a loss can affect the legal conceptualization of the harm." Chamallas \& Kerber, supra note 25, at 816. In Lynch, the court held that emotional disturbance does not qualify as a legally cognizable harm. There, the female plaintiff alleged that as a consequence of the defendant's statement accusing her of immorality, her husband forced her to leave their home. See id. at 816-19.

Sometimes courts in sexual slander cases mentioned emotional distress injuries, even when their assessment was not critical to the plaintiff's recovery. In Kennedy v. Gifford, the defendant said that "everybody knows that she [the plaintiff] has had a litter of pups by old Troop." 19 Wend. 296, 297 (N.Y. Sup. Ct. 1838). The court did not have to deal with the special damages question because bestiality was a crime under New York law, but the court expressed sympathy with the plaintiff, writing that it is "difficult to conceive of words more forcibly indicative of malice, of such withering influence upon the character of the plaintiff, or more harrowing to the feelings of a female whose moral sense was not totally depraved." Id. at 330-31 (emphasis added). In one more recent case, Interstate Co. v. Garnett, the Mississippi Supreme Court in a sexual slander case spoke of "the uncurable wound to the victim's feelings, the contempt and disrepute into which she is plunged, her exclusion from the society of the pure and other degrading consequences of the slander" being the "direct kinds of injuries suffered in reputation." 122 So. 373, 377-78 (Miss. 1929) (emphasis added). 
sad and dejected in mind and enfeebled and languid in body, for a long space of time, during which time she suffered and underwent great pain and anguish, and was hindered and prevented from transacting her necessary affairs and business; and the plaintiffs were compelled to employ servants, nurses and physicians, at great pecuniary expense. ${ }^{188}$

Although the plaintiff in that Maryland case, Shafer $v$. Ahalt, won a $\$ 1500$ award from the jury, the appellate court reversed the judgment on the basis that she had not proved special damages. The court explained, "pecuniary loss to the plaintiff is the gist of the action" when a slander plaintiff must prove special damages. ${ }^{189}$

This is a suit by the husband and wife to recover damages of the defendant for charging the plaintiff's wife with adultery, and the question is, whether the sickness of the wife resulting from this slanderous charge is sufficient to prove special damage. In cases of this kind special damage is that which is naturally the consequence of the words spoken. Now it cannot be said that sickness is the natural consequence of defamatory or slanderous words... The rule of law in regard to special damage was adopted with reference to common and usual effects and not such as are occasional or accidental. ${ }^{190}$

Because neither the plaintiff's dejection of mind nor her enfeeblement of body was considered a "natural consequence" of the offending statement, she had not established special damages. Instead, as in similar cases involving female plaintiffs, the court implied that her reaction was that of someone with peculiar "sensibilities and temperament."191 Thus, the Maryland Supreme Court found it undesirable to hinge recovery on what they viewed as the plaintiff's fragility. ${ }^{192}$

188. Shafer v. Ahalt, 48 Md. 171, 172 (1878). Although this case followed Maryland's 1838 adoption of a slander per se rule for unmarried women, it precedes the state's 1881 adoption of such a rule for all women. $1838 \mathrm{Md}$. Laws $114,1881 \mathrm{Md}$. Laws 444, discussed supra note 8 . Thus, special damages were still required for this plaintiff's case to be actionable.

189. Id. at 173 (emphasis in original).

190. Id. at 173-74 (emphasis in original) (citation omitted). The Shafer court cited Allsop v. Allsop, 2 L.T.R. 290 (1860), in which the plaintiff wife, charged with adultery, "became and was ill for a long time, and unable to attend to her necessary affairs and business, and the plaintiff [husband] was put to and incurred much expense in and about the endeavouring to cure her of the illness." Id. There, it was held on demurrer that the plaintiff had stated no cause of action based solely on these damages. Other judges in their concurring opinions in Allsop suggested that the alleged damages were inadequate because they were subjective. One wrote that "the mischief done depends entirely on the temperament of the individual affected by the words spoken," and another wrote, "the peculiar temperament of the party injured would be a bad standard by which to estimate damage." Id. at 291-92 (opinions of Pollock, C.B., and Martin, B., respectively).

191. Shafer, $48 \mathrm{Md}$. at 173.

192. While denying that "sickness is the natural consequence of defamatory or slanderous words," the court noted that it could be a consequence, "depending in a great measure upon the sensibilities and temperament of the person." Id. (emphasis in original). The Shafer court discusses and quotes Allsop, in which the slandered woman's husband alleged that, among other things, his wife became ill and was "unable to attend to her necessary affairs and business" as a consequence of the slander. 2 L.T.R. at 290. In turn, Mr. Allsop argued that he was "put to and 
Stating a similar rationale, a Texas court in 1864 reached the same decision on analogous facts. The court in McQueen v. Fulgham, ${ }^{193}$ however, began its opinion using language that made it seem sympathetic to the harms associated with emotional upset, suggesting that it recognized the potential for such harms to constitute special damages. There, the young, unmarried plaintiff was said to have been pregnant. ${ }^{194}$ She alleged that as a consequence of the slander she had suffered "dejection of mind and enfeeblement of body, so as to prevent [her] from attending to her ordinary business, and laid as aggravation the injury to her fame, name and repute." 195 In a subsequent count, she went on to specify that "for the clearing of the said scandal" she had been "subjected to great trouble and expense in procuring the advice of counsel and the testimony of witnesses, greatly to her damage" and she sought $\$ 10,000 .{ }^{196}$ A witness who had known the plaintiff for twelve years and who saw her "as often as once a month" during that time, said that he saw her soon after the slanderous report and that that he

observed a great change in her; that before the period in question she had been cheerful enough, though quiet and modest, but, after the report, seemed greatly changed, being depressed and very unhappy, silent and much dejected; that she would sit at dinner and refuse to eat as formerly; that previously she had been accustomed to assist in doing the household work of her father's family, but she has become ... unable from her state of mind to attend to her duties and perform her labor in the family as formerly. That she was about seventeen years of age and lived in her father's family. Witness had seen her several times of late, and her health seemed improved; she had become more able to attend to her ordinary

incurred much expense in and about the endeavoring to cure her of the illness which she labored under [and] lost the society and association of his said wife for a long time in his domestic affairs." 2 L.T.R. at 290. In that case, Pollock, C.B., stated that "the mischief done depends entirely on the temperament of the individual affected by the words spoken, whether any damage would result or not." Id. at 291. The Shafer court also cites with approval the opinion of Martin, B.: "The special damage is that which is naturally the consequence of the act done, and the peculiar temperament of the party injured would be a bad standard by which to estimate damage." Id. at 292. The Shafer court did not quote the opinion of Bramwell, B., in Allsop but it, too, is interesting for its gross lack of sympathy and incredulity toward the plaintiff.

If this is a good allegation of special damage, it would be equally good to say that a person underwent great mental pain and suffering; and if so, all words causing mental pain may become actionable, unless indeed some distinction can be drawn between the suffering of mind and body. I therefore decide the case on the ground that the damage alleged is not a natural consequence of the words spoken-that is, a natural consequence of them in point of law.

Id. at 292. Contra McQueen v. Fulgham, 27 Tex. 463 (1864) (in dicta, recognizing that sexual slander may prey upon her mind and impair her health as to occasion pecuniary loss for which an action will lie).

193. 27 Tex. 463.

194. The statement was susceptible to alternative interpretations- that she either gave birth to a bastard child or that she miscarried. Id. at 465.

195. Id.

196. Id. 
duties, and when witnesses last saw her she was at work. ${ }^{197}$

The court appeared at first to be sympathetic and inclined to uphold the verdict and $\$ 2500$ award, stating that it could not say, "as a question of law, that the words of a ribald and malign slanderer may not prey like a canker upon the mind and health of a sensitive and nervous female, until the one is unsettled and the other impaired and destroyed." 198 The court continued, in a similar vein, that it could not say as a matter of law that "pecuniary injury would not result from the loss of health, and the inability to discharge her ordinary and accustomed domestic labor."199

The McQueen court went on, however, to attack on multiple bases the plaintiff's proof that her ill health and consequent inability to perform her duties had, in fact, resulted from the slander. ${ }^{200}$ Specifically, the court questioned the quality of her evidence, noting that the witness had only intermittent opportunities to observe her health and that, by the witness's own account, the plaintiff's illness and inability to labor had been temporary. ${ }^{201}$ The court suggested that testimony of the plaintiff's family members, friends who were in daily contact with her, and her physician would have been more probative. ${ }^{202}$ The court concluded by observing that there was no "effort to show that she was accustomed to derive any pecuniary benefit from the labor in the family which she usually performed, or that it was of such a character as to justify the inference that the inability to perform it must have been attended with pecuniary loss." 203 The court overturned the jury's findings of fact and remanded for a new trial on the basis that the plaintiff's evidence of damages was not sufficient to support the verdict. ${ }^{204}$ However, in overturning the jury decision, the court failed to identify clearly the particular infirmity in her case, as the opinion alluded to both causation issues and to the injury alleged as nonpecuniary. ${ }^{205}$

197. Id. at 466 (emphasis added).

198. Id. at 469 (emphasis added). At no point in the opinion does the court suggest that the female plaintiff was especially sensitive compared to other women. Therefore, this characterization as "sensitive and nervous" would appear to state the court's characterization of all women. In this sense, the opinion is akin to others in which courts acknowledged that sexual slander would naturally hurt the feelings of the person about whom they were spoken. See supra note 9.

199. McQueen, 27 Tex. at $469-70$.

200. Id. at 470.

201. Id.

202. Id.

203. Id. at 471

204. Id.

205. Id. The court said the question before it was "whether the testimony before the jury establishes with sufficient certainty to sustain the verdict, the fact that the plaintiff did in reality sustain any pecuniary loss or damage as a direct and natural effect of the imputed slanderous words spoken of her by the defendant." Id. at 470 .

Even in jurisdictions that treated statements impugning chastity as slander per se, there are judicial indicia that courts recognized loss of intercourse with friends as "a natural consequence" of defamation. See, e.g., Haldeman v. Martin, $10 \mathrm{~Pa} .369,372$ (1849) (asserting that damages did not have to be specifically pleaded because they were presumed in this case, but that plaintiff was nevertheless permitted to show "she had been deserted by her acquaintances, in consequence of the slander, without having alleged the fact in her 
In both of these cases, as well as in others of the era, courts expressed skepticism that a slanderous statement would logically cause either emotional upset or physical illness. They were, indeed, incredulous at the argument that such a link might exist and sometimes mocked the plaintiff for her weakness if, in fact, the offending statement had upset her so. ${ }^{206}$ The findings of these courts were, of course, in sharp contrast to earlier cases that had stated how logical it was for sexually slandered women to be upset. $^{207}$

A number of post-Bradt New York cases also relied on causation issues to deny the plaintiff relief, but the causation issues were somewhat different to those in McQueen and Shafer. The court in Olmsted v. Brown, ${ }^{208}$ for example, was sympathetic to a husband who alleged loss of his wife's service after she was defamed by an allegation of adultery. The court wrote:

\begin{abstract}
A husband having by law a right to the services of his wife, whether he requires them or not, and being bound to maintain her, in sickness and in health, anything that diminishes the value of the right, or increases the burden of the duty, necessarily occasions a pecuniary loss to the husband. Hence he may maintain an action for slanderous words spoken of the wife, affecting her health and her spirits, without proving that her services were of any value, or that he has paid out anything for medicine and attendance. ${ }^{209}$
\end{abstract}

Thus, the court presumed a pecuniary loss to a husband whose wife had become ill. ${ }^{210}$ The burden of supporting the female plaintiff, by law on her husband, was seen as having increased by virtue of the slander, even absent proof of medical or other costs associated with the illness. The court did not question-as it had in other caseswhether defamatory statements might, in fact, naturally and proximately cause such distress. ${ }^{211}$ Nevertheless, on the basis of a different causation problem, the court overturned the jury's verdict and its $\$ 1000$ award to the plaintiff, because she had not established the causal link between the defendant's uttering the statement and the plaintiff's hearing it. ${ }^{212}$ In that particular case, the plaintiff had learned of the statement

declaration"). It is therefore especially unusual that such consequences were treated with such skepticism in jurisdictions where special damaged had to be proved.

206. See generally Chamallas \& Kerber, supra note 25, at 863.

207. See supra Section III.B.

208. 12 Barb. 657 (N.Y. Gen. Term 1852). The jury awarded the plaintiff $\$ 1000$, which was upheld on appeal. $I d$. at 659.

209. Id. But see Keenholts v. Becker, 3 Denio 346 (N.Y. 1846) (husband sued in defamation when he lost services of his slandered wife; court held that loss did not constitute pecuniary injury).

210. This decision is somewhat reminiscent of the gendered double standard evident in early loss of consortium cases, when men were presumed to be entitled to the services of their wives, such that a husband's loss of this type was viewed as "material" or "temporal." The same was not true for women plaintiffs who lost the services of their husbands; women's losses were characterized as merely "emotional" and their recovery was accordingly denied. See supra note 117 and accompanying text (opinion of Lord Wensleydale in Lynch v. Knight, 11 Eng. Rep. 854 (H.L. 1861)).

211. See supra notes $188-207$ and accompanying text.

212. Olmsted, 12 Barb. at 660. 
from a witness to the defendant's original utterance of it. The court apparently believed that the defendant could not have reasonably foreseen the witness's communication of the statement. The court observed that none of the witnesses was authorized to communicate to the female plaintiff, and it did not "appear that any of them had the intention and occasion which would have justified them in communicating the slander, or that they sustained relations from which such intentions could be presumed."213

This focus on causation became a recurrent theme in later cases that denied

213. Id. at 666 . The court wrote that the defendant proved

that the words had come to the knowledge of his wife, and that she had been made sick by them; but he had already proved that they were uttered by the defendant to the witnesses, none of whom were authorized to communicate them to the plaintiff's wife; nor did it appear that any of them had the intention and occasion which would have justified them in communicating the slander, or that they sustained relations from which such intentions could be presumed. To connect the defendant's speaking of the words with this injury imputed to that speaking, might have embraced all the slanders and tattling of the whole neighborhood, and made him responsible for the effects which his own acts would not have produced.

Id; see also Beach v. Ranney, 2 Hill 309, 310 (N.Y. Sup. Ct. 1842). In Beach, the court said that the special damages pleaded, including that plaintiff "suffered pain of body and mind-that her neighbors had shunned her-that she was turned out of the moral reform society" were insufficient to maintain action for slander. For a detailed explanation of the Beach case, see discussion infra notes 221-35 and accompanying text.

In fact, this sort of ruling was not unusual at the time because courts tended to impose strict "proximate cause" requirements on slander plaintiffs, limiting recovery to the consequences of the defendant's publication of the offending statement and not attaching liability for damages caused when others repeated the slander. KEETON, supra note 49, §112, at 795. The law on this point was greatly relaxed in the twentieth century, and a defendant is now liable for reasonably foreseeable repetition of an offending statement. Id.

In a similar case, Terwilliger $v$. Wands, the court determined that any emotional injury the plaintiff suffered had been due to repetition of the defendant's slander by a friend of the plaintiff. 17 N.Y. 54 (1858). The court wrote:

It would be highly impolitic to hold all language, wounding the feelings and affecting unfavorably the health and ability to labor, of another, a ground of action; for that would be to make the right of action depend upon whether the sensibilities of a person spoken of are easily excited or otherwise; his strength of mind to disregard abusive, insulting remarks concerning him; and his physical strength and ability to bear them.

Id. at 60 . The court also said that the plaintiff had proved inadequate special damages, in particular his extreme emotional upset, which made it impossible for him to work. The court noted that the plaintiff became ill some time after the defendant's communication because "the story was all over the county." Id. at 59 . The fact that this case was brought by a male plaintiff makes it especially interesting.

Other courts took a different position on liability for repetition by others. In Kelley v. Dillon, the court said that

a bare rumor or report is sufficient to justify the retailing of slander, and character would be at the mercy of the artful and designing, as such defences could be easily manufactured beforehand to suit any emergency. We will not drive parties out of Court, with injured characters, to hunt down those who first gave birth to calumnious reports.

5 Ind. 426, 427 (1854). See also Hardin v. Harshfield, 12 S.W. 779 (Ky. 1890). 
plaintiff's recovery when the injury alleged was in the nature of hurt feelings. The U.S. Supreme Court wrote in 1875 in Pollard v. Lyon, a sexual slander case from the District of Columbia, that "[s]pecial damage is a term which denotes a claim for the natural and proximate consequences of a wrongful act." ${ }^{214}$ Courts, however, were already in the practice of construing "natural and proximate" rather narrowly, not acknowledging the reasonable foreseeability of emotional distress when a woman had been sexually slandered, ${ }^{215}$ nor even the reasonable foreseeability that her relationships would be affected. Unlike some of their predecessors, these later courts often did not specifically reject the validity of the special damages argued based on whether they were pecuniary or not. Instead, they frequently said that the plaintiff had not proved that the special damages she suffered, damages that were frequently in the nature of emotional upset, were a consequence of the slander. ${ }^{216}$ Courts offered this skepticism in spite of a lack of evidence or other indication in these cases that some alternate explanation accounted for the injury alleged. Rather, the courts spoke in terms reminiscent of the "egg shell" plaintiff doctrine, ${ }^{217}$ specifically rejecting the accepted rule that in regards to physical injuries that the defendant must take a vulnerable plaintiff as he or she is. In doing so, courts generally refused to permit recovery, often based on the fact the plaintiff's response to the offending words was subjective. ${ }^{218}$

Courts' denials of recovery were occasionally more persuasive in their logic in the rare instances when they noted that the essence of defamation law was injury to reputation and that the occurrence of emotional upset did not prove the "effect of the

214. 91 U.S. 225, 236 (1875) (emphasis added).

215. See supra notes 188-205 and accompanying text (discussing Shafer and McQueen). This trend is also evident in courts' handling of emotional distress injuries arising from other torts. See Chamallas, supra note 25, at 489-503, 515-19.

216. See, e.g., Vicars v. Wilcocks, 103 Eng. Rep. 244 (K.B. 1806) (wrongful act of third party in response to a slanderous statement could not constitute special damages because it was actionable in and of itself); contra Knight v. Gibbs, 110 Eng. Rep. 1124 (K.B. 1834) (third party's wrongful expulsion of the plaintiff from her lodgings constituted special damages, even though it was a wrongful act, because "the whole cause of the special damage proceeds from the defendant himself; nothing is done by any other person."). The Knight court distinguished the matter from Vicars $v$. Wilcocks, stating that "there were two distinct causes of the special damage there; the words used, and an act done by a third person; and the damage might have resulted from either. Id. at 1125 .

One commentator offered this statement regarding natural consequences as special damages.

But it is obvious that an illegal act, equally with a legal act, may be the natural, and even the intended, consequence of a publication; and, where, as in the case of a promise to marry, the breach of it, although illegal, is nevertheless a natural consequence of the slander, in that case the illegal act constitutes special damage, but, where the breach of the contract is not the natural consequence of the publication, it does not constitute special damage, not because it is an illegal act, but because it is not the natural consequence of the slander.

ADDISON, supra note 52, at 200 (citing TowNSHEND, supra note 37, at 273).

217. The egg shell plaintiff doctrine holds that a defendant takes his plaintiff as he finds him, even with physical infirmities that make the plaintiff more vulnerable to the harm caused by the plaintiff. See, e.g., Vosburg v. Putney, 50 N.W. 403 (Wis. 1891).

218. See, e.g., Shafer v. Ahalt, 48 Md. 171 (1878). 
injurious imputation upon other persons than the party bringing the action."219 In spite of one or two decisions making this point, however, later New York decisions almost always relied upon a lack of established causation between the defendant's statement and the injury suffered, whether that injury was social alienation or emotional upset, to deny recovery. ${ }^{220}$

\section{Rejection of Relational Injuries}

A few cases from this era are even more confusing in that they appear to contradict the basic rule of the early Olmsted and Williams decisions which held that slander adversely affecting the plaintiff's relationships constitutes sufficient damages to make the plaintiff's slander claim actionable. These decisions retreat from Olmsted and Williams, but they do so not by openly rejecting the notion that injuries to relationships may have pecuniary consequences. Rather, they do so, in the manner of Shafer and McQueen, by identifying problems with the causal link between the offending statement and injured relationship.

In Beach v. Ranney, ${ }^{221}$ for example, the female plaintiff was married, but she was apparently separated from her husband at the time of the offending statement. The slanderous statement said she was a thief and "charg[ed] her with incontinence.",222 She pleaded special damages as a consequence of these statements, even though the former, being slander per se, did not require it. She said she "suffered pain of mind and body;

219. Wilson v. Goit, 17 N.Y. 442 (1858). In this case, as in several others of the time, the husband alleged that he had lost the services of his slandered wife when she was made "sick and diseased in her mind and body" and he had to employ "assistance in his household affairs." Id. However, in addition to holding that this did not constitute sufficient special damages, the court stated that "an action of slander, which is allowed solely for the vindication of an injured reputation, would be plainly perverted if used as a means of punishment where the slanderous words were not actionable themselves ... and where the plaintiff's character had not suffered in the slightest degree." Id. at 445.

220. See, e.g., Pettibone v. Simpson, 66 Barb. 492 (N.Y. Gen. Term 1873). This tendency to view such damages as unexpected and unforeseeable is rather like that observed with respect to the tort of negligent infliction of emotional distress. See Chamallas \& Kerber, supra note 25, at 837-38.

221. 2 Hill 309, 310 (N.Y. Sup. Ct. 1842).

222. Id. This case is also interesting procedurally because the woman about whom the statements were made was not permitted to bring the case, in which she was required to prove special damages for her claim to be actionable. Rather, her husband had to sue. The court wrote, "But when words spoken of the wife are only actionable on proof of special damages, the husband must sue alone." Id. at 316 (citing STARKIE ON SLANDER, supra note 34, at 151, 159-60, and cases collected therein).

Legal damages, to support the action, must be such as result to the husband, and they should be so laid in declaring. He is bound by law to provide support and maintenance for the wife; and if she is deprived of the gratuitous aid of friends in consequence of the slander, the damage, in a legal point of view, results to the husband.

Id. At the end of the day, then, because the husband bears legal responsibility for supporting his wife, he receives any damages awarded. The injury is reduced to purely economic terms-the fiscal support of the wife. Again, the injury is perceived as one cognizable in the marketplace; injuries that are personal to the female plaintiff are not acknowledged. 
her husband had abandoned her; her neighbors refused to assist her as they had before been accustomed to do." 223 She argued that "one Smith who had been in the habit of assisting her to fuel, clothing and provisions, refused to do so any longer; and the like in relation to one Raymond." 224 . She also argued that "she had been turned out of the Moral Reform Society" and that "children threw dirt, clubs, stones and other missiles into her house, and called her a strumpet." ${ }^{225}$ The court denied any pecuniary nature with respect to most of the injuries she alleged. The court wrote:

The allegations that she suffered pain of body and mind; that her neighbors shunned her; that she was turned out of the Moral Reform Society; that her husband abandoned her and the like, do not show any pecuniary loss, or legal damage. The wrongful act of the children in throwing missiles into the house, and calling Mrs. Beach hard names, is quite too remote a consequence of the slander to be charged to the account of the defendants. ${ }^{226}$

The court analogized the case to earlier English decisions in which courts had held that the tortious acts of third parties, for example, in wrongfully discharging the plaintiff from his employment as a consequence of a defamatory statement, could not be "the legal and natural consequence of the words spoken by the defendant."227 Rather, those

223. Id. at 310 .

224. Id.

225. Id.

226. Id. at 314 .

227. Id. at 314-15 (citing Vicars v. Wilcocks, 8 East. 3, 103 Eng. Rep. 244 (1806)). The court also discussed Vicars in which the plaintiff claimed that "in consequence of the words, persons assembled and seized and threw the plaintiff into a horse pond by way of punishment for his supposed transgression." Id. at 314. There, the court said that the tortious behavior of these third persons, even though responding to the defendant's slander, did not constitute the requisite special damages. Id. at 314-15. This is also reminiscent of Chief Justice Savage's dissent in Moody v. Baker, 5 Cow. 351, 358-59 (N.Y. Sup. Ct. 1826), where he said the wrongful act of a person who breached a contract could not be attributed to the speaker of slander whose statement motivated the breach. See supra notes 88 and 125; see also Brentman v. Note, 3 N.Y.S. 420 (N.Y. City Ct. 1889) (holding that male plaintiff had no cause of action in slander against man whose derogatory statement about his property purportedly caused a contract of sale to be breached; rather, plaintiff's cause of action was against the man who broke the contract to buy the property).

Interestingly, Lord Wensleydale, in his opinion in Lynch v. Knight, disagreed with this narrow view of causation when the actions of third parties, responding to a defamatory statement, are the more direct agents of the damage. 11 Eng. Rep. 854, 863-64 (1861). After analyzing the issue in Lynch as one of a wife's entitlement to consortium with her husband, see supra note 117 and accompanying text, he acknowledged his colleagues' focus on causation issues in that case. Lynch, 11 Eng. Rep. at 862-64. Specifically, he opines that Lord Ellenborough articulated "too restricted" a rule in Vicars $v$. Wilcocks. Lord Wensleydale wrote:

I cannot agree that the special damage must be the natural and legal consequence of the words, if true. Lord Ellenborough puts an absurd case, that a Plaintiff could recover damages for being thrown into a horse pond, as a consequence of words spoken; but I own I can conceive that when the public mind was greatly excited on the subject of some base and disgraceful crime, an accusation of it to an assembled mob might, under particular circumstances, very naturally produce that result, and 
actions were the legal responsibility of the third party, who himself had committed a legal wrong.

The court went on to say that some of the damages alleged-presumably the withholding of fuel and clothing-might have been sufficient special damages if "properly laid" and if Mrs. Beach were a "feme sole," meaning a single woman. ${ }^{228}$ The court noted that "[p]ersons who had before been accustomed to receive and provide for her gratuitously, refused after the slander to do so any longer until she should clear up her character; and two persons in particular are mentioned who had witheld their former bounty." 229 The court observed that these averments were flawed, however, because these incidents were not "the direct and immediate" consequence of the slander. ${ }^{230}$ Rather, the court said the immediate consequence of the offending words was Mr. Beach's abandonment of Mrs. Beach, "leaving her destitute."231 The court observed that, only then did "Smith, after providing for her for a time, finally with[hold] his bounty; and Reynolds refused any longer to receive her as a welcome guest in his family." ${ }^{, 32}$ Later in the opinion, the court again relied on causation problems to clarify its conclusion that the relational damages that Mrs. Beach sustained were "not alleged to have resulted from the speaking of the words; but from the fact that she lived apart from her husband under a deed of separation."233 The court did not explain why Mr. Beach's abandonment of Mrs. Beach, leaving her destitute, was not

a compensation might be given for an act occurring as a consequence of an accusation of that crime.

Id. at 864 .

228. Beach, 2 Hill at 315. The court does not explain why Mrs. Beach's status as a married woman rendered her allegation of pecuniary damages, for example, the loss of fuel and clothing, insufficient. Based on cases from that era, one can presume that because her husband was still legally obligated to provide for her, the injury was not to her, but rather to him. Given that the husband, too, was a named plaintiff in the action, the reasons for the court's dismissal of this injury are unclear. The court wrote:

The suit, as to the words not actionable per se, should have been brought by the husband alone. When words spoken of the wife are actionable of themselves, or when the wife suffers any other injury, as a battery or imprisonment, she must join with her husband in seeking legal redress. The declaration concludes to the damage of both, for the action survives to the wife if the husband die before the damages are recovered. But when words spoken of the wife are only actionable on proof of special damage, the husband must sue alone. Legal damages, to support the action, must be such as result to the husband, and they should be so laid in declaring. He is bound by law to provide support and maintenance for the wife; and if she is deprived of the gratuitous aid of friends in consequence of the slander, the damage, in a legal point of view, results to the husband.

The fact that the plaintiffs lived apart under a deed of separation cannot, I think, affect the question. The husband was still bound to provide for the wife; and what she lost in the way of support in consequence of the slander, was in judgment of law the loss of the husband.

Id. (citations omitted).

229. Id. at 315.

230. Id.

231. Id.

232. Id. at 315 (the court limited this objection to the first count).

233. Id. 
sufficient special damages to make her claim actionable. ${ }^{234}$ As for the fact the plaintiff "was pained and enfeebled in mind and body; and that children assailed her with missiles and opprobrious epithets," the court found these "not sufficient" to constitute special damages. ${ }^{235}$ The court thus rejected two different varieties of relational damages, one as nonpecuniary, the other as not naturally resulting from the slander.

The Beach court's refusal to recognize that a plaintiff's rejection by the families who had previously entertained her might be the "natural and immediate consequence of the speaking" of words impugning her chastity evinced-indeed foretoldincreasing judicial hostility to damages based on injured relationships. The court might easily have concluded that her neighbors' ostracism of the plaintiff, and the pecuniary consequences of those acts, had naturally followed from the offending statement. Thus, in contrast to Olmsted, Williams, and Fuller, the New York court in Beach dramatically pulled back from recognizing either injuries to relationships or emotional distress injuries as the basis for special damages.

Ultimately, this apparent judicial backlash against sexual slander cases-an antipathy reflected in increased judicial skepticism of the injuries on a variety of bases-was stifled. In these states where judges had been slow to embrace sexual slander of women as a fourth slander per se category, legislatures proved more receptive than the courts to these claims, thus, ultimately eliminating the requirement that these plaintiffs prove special damages. ${ }^{236}$ Whether responding to their sympathy for these wronged women or merely acting from a paternalistic desire to preserve the appropriate gender and class social order, legislative bodies ultimately eliminated the need for the machinations and sometimes contorted rationale that had been offered by judges considering these nineteenth-century cases.

\section{E. Other Indicia of Women's Virtue as Property}

Other markers of the "reputation-as-property" concept, with its link to the marketplace, are evident in cases from this period. Recall that this property-based concept of reputation means that not all reputations are equal; an individual's reputation is something he or she earns through effort, as, for example, a craftsman earns a reputation for fine workmanship through the work that he does. ${ }^{237}$ No baseline reputation exists for any given virtue, including chastity, and a particular woman's reputation for chastity will accordingly vary with her conduct. This conception of reputation is in contrast with the reputation-as-dignity or reputation-as-honor theories, both of which hold that all persons are presumed to have good reputations simply by

234. The court might have implied that Mrs. Beach's cause of action was against Mr. Beach, given that he remained legally obligated to support her. See supra notes 222 and 228 . His behavior was arguably like the behavior of any other third party who, acting on a slanderous statement, committed a wrong. The plaintiff's action, if she had one, was against that third party. See supra note 216 . This theory would not have worked for this female plaintiff, of course, as she could not have sued her husband, and, indeed, the court explains that any cause of action was, in fact, Mr. Beach's.

235. Beach, 2 Hill at 315-16.

236. For a discussion of the history of many of the states' judicial and legislative action on this front, see King, supra note 2, at 81-90.

237. See supra notes 34-38 and accompanying text (discussing Post, supra note 32). 
virtue of their membership in the community. ${ }^{238}$

This marketplace or reputation-as-property concept is present in the admission of evidence of a specific female plaintiff's reputation for chastity in sexual slander cases. The evidence is admitted because it is information that might either mitigate damages or mean that the plaintiff was deemed to have such a poor reputation for chastity that she was in no need of - nor indeed, entitled to - the legal protection otherwise afforded by defamation law. ${ }^{239}$ The general and "well established" rule followed in the New York cases was that a defendant in a slander action could mitigate damages he had to pay by "proving the general bad character of the plaintiff before and at the time of uttering the slanderous words imputed to him."240 Many other jurisdictions also

238. See supra notes 39-48 and accompanying text (discussing Post, supra note 32). See also Long v. Long, $4 \mathrm{~Pa}$. 29 (1846) (stating that "character is more dear to a person than property," implying that the injury is not compensable in the marketplace and suggesting a dignity-type injury). This concept of reputation is also reflected in some New York cases, including Williams v. Holdredge, 22 Barb. 396 (N.Y. Gen. Term 1854), in which the court wrote in dicta:

Man being formed for society, and standing in almost constant need of the advice, comfort and assistance of his fellow creatures, it is highly reasonable that any words which import the charge of having a contagious distemper should be in themselves actionable, because all prudent persons will avoid the company of a person having such distemper. It makes no difference whether the disease be owing to the visitation of God, to accident or to the indiscretion of the party therewith afflicted, for in every one of the cases the being avoided, from which the damage arises, is the consequence upon which the action is predicated.

Id. at 398. See also Shilling v. Carson, 27 Md. 175 (1867) (holding that every woman is presumed chaste until the contrary is shown).

239. Again, there is a parallel to be drawn with the law of seduction. Because the wrong redressed in a seduction action was the woman's loss of sexual chastity, a sexually active woman was seen as having no virtue to lose. A seduction plaintiff's sexual virtue and good reputation were critical to her successful seduction action. Larson, supra note 15 , at 387 . While courts could have handled this issue as one of the truth or falsity of the statements, nineteenthcentury courts very rarely did. Indeed, nineteenth-century sexual slander decisions almost never take up the issue of the offending statements falsity or truthfulness. King, supra note 2, at 109.

240. Douglass v. Tousey, 2 Wend. 352 (N.Y. Sup. Ct. 1829) (collecting cases). In Douglass, the woman plaintiff sued on the basis of the statement, "you are a common thief, you stole my wife's dress." The defendant sought to introduce evidence that the plaintiff had a reputation as having a "bad character" and being a "common prostitute" in the town in which she formerly lived. In spite of the general principle stated above, in part, because her character at this time prior to the offending statement was not probative. Id. The court also observed: "The general character is the estimation in which a person is held in the community where he has resided, and ordinarily, the members of that community are the only proper witnesses to testify as to such character." Id. This statement supports a notion of reputation as local and community-based. See also Anonymous, 8 How. Pr. 434 (N.Y. Sup. Ct. 1853) (holding "mitigatory circumstances" to be made an issue if the defendant pled a general denial).

In Bush v. Prosser, the court permitted evidence of the bad acts of the plaintiff's family in mitigation of the damages sought when the male plaintiff was said to have kept a "house of ill fame." 11 N.Y. 347 (1854). These bad acts included evidence of the "lewd conduct" of plaintiff's wife and daughter, the latter of whom supposedly acted as a prostitute at the house. Id. The appellate court ruled that the evidence should have been admitted. In other jurisdictions, 
followed this rule, regularly making a woman's sexual practices fair game for testimony in a sexual slander suit. ${ }^{241}$ Thus, the value of each woman's reputation-and therefore what she could recover on the basis of having been slandered-varied according to her behavior and the nature of the reputation for chastity that she had earned. ${ }^{242}$

\section{CONCLUSION}

[T] he chastity of women, being of the utmost importance, as all property depends on it ....

Samuel Johnson ${ }^{243}$

The analysis here has revealed a number of ways in which the nineteenth-century law of sexual slander was gendered. The most obvious, surely, is the gender double standard associated with statements impugning a plaintiff's chastity. This double standard was ultimately expressly embraced by most of the fifty states as their various legislatures and courts recognized, over the course of the nineteenth century, that

courts similarly did not permit defendants to offer evidence that the plaintiff had a bad reputation prior to the offending statement. E.g., Smith v. Buckecker, 4 Rawle 295 (Pa. 1833) (rejecting defendant's offer of evidence that plaintiff, whom he slandered by calling her a whore, was a "reputed thief" and that plaintiff's own sister reported her to be a whore); Fitzgerald v. Stewart, $53 \mathrm{~Pa} .343$ ( $\mathrm{Pa}$. 1866) (stating that the general character of the plaintiff may be assailed, but particular reports or reports of guilt of particular acts, cannot be admitted into evidence, even in mitigation); Kennedy v. Gifford, 19 Wend. 296 (N.Y. Sup. Ct. 1838) (holding that neither particular reports nor public reputation regarding the truth of the statement, nor of kindred charges against the plaintiff, are admissible); Shilling, $27 \mathrm{Md} .175$ (holding that every woman is presumed chaste until the contrary is shown).

241. See, e.g., Williams v. Greenwade, $33 \mathrm{Ky}$ (4 Dana) 432 (1835); Redfearn v. Thompson, 73 S.E. 949 (Ga. Ct. App. 1912); Webb v. Gray, 62 So. 194 (Ala. 1913); McCabe v. Platter, 6 Blackf. 405 (Ind. 1843); Patterson v. State, 12 Tex. Ct. App. 458 (1882) (holding that defendant in criminal slander action may "justify by proving the truth of the particular imputation" or "by proving that her general reputation for chastity" was "bad"). In Enquirer Co. v. Johnston, the court wrote that "One's reputation is the sum or composite of the impressions spontaneously made by him from time to time, and in one way or another, upon his neighbors and acquaintances." 72 F. 443, 446 (7th Cir. 1896).

242. One Texas court wrote, "It is the pure and chaste woman that comes within the intended protection of the law, and not the lewd and the unchaste." Patterson, 12 Tex. Ct. App. 458 (citing Bridgman v. Hopkins, $34 \mathrm{Vt} .532(1861)$ ). As with the law of seduction, then, the law of sexual slander tended to protect only women with spotless reputations for sexual virtue. Larson, supra note 15 , at 387 .

243. This statement is attributed to Samuel Johnson. JAMES BosWELL, LIFE OF JOHNSON 702 (4th ed. 1953). Johnson apparently made the statement in the context of a discussion of "legitimation by subsequent marriage," which was permitted by Scottish law. Johnson goes on to state that "they who forfeit [chastity] should not have any possibility of being restored to good character; nor should the children, by an illicit connection, attain the full rights of lawful children, by the posteriour consent of the offending parties." Id. Although Johnson apparently was not referring in any way to sexual slander, the quote is eerily appropriate to my conclusion that the law treated women's sexual virtue as a type of property. 
sexual slander is a per se slander only when about a woman plaintiff, but not when concerning a man. The normative power of this designation, reinforcing the primacy of women's sexual virtue as it does, is enormous. Yet, only a few states made what was good for the proverbial gander, good also for the goose, by designating all statements that undermined one's reputation for chastity to be slander per se, without regard to the plaintiff's gender.

Another way in which slander law more generally reflects a male bias is in the law's very requirement that special damages be established by some pecuniary injury. Certainly during the nineteenth century, and to some extent even now, women were far less likely than men to own or control property. They were therefore at a considerable disadvantage when it came to establishing the requisite out-of-pocket or other economic injury. Indeed, this is just the sort of subtle gender bias that Chamallas has observed in other contexts in tort law.

Then, of course, there are the nineteenth-century cases that were decided before particular states recognized sexual slander as slander per se. Assessing the meaning, let alone the significance, of this line of cases is a challenging task, in part because the opinions show relatively little consistency over the years, yet as the headings used in Part III indicate, several short-lived trends can be detected in a period shorter than a century. Following the lead of English courts, U.S. courts initially required sexual slander plaintiffs to show pecuniary injury, but judges were relaxed about what harms were deemed pecuniary. They tended to conclude, rather uncritically, that a revocation of hospitality by family or friends was a pecuniary harm, analogizing it to a man's loss of customers or livelihood in his trade or profession. Loss of a marital engagement was also typically sufficient, and courts frequently waxed poetic about the importance of marriage to a woman's status, while also analogizing marital engagement to commercial contract law in order to assert its tangible economic value. In short, courts in these earliest decisions converted injuries that were intuitively relational, personal, and dignitary into a form of property, recognizing injury to reputation on that basis.

At the same time, courts were generally unsympathetic to plaintiffs who argued that they had suffered emotional distress and attendant physical illness, even when the plaintiffs carefully pleaded that such injuries had caused adverse financial consequences. New York courts in particular tended to frown on the emotional distress genesis of such damages claims. They generally denied such claims on the straightforward basis that the injuries were not pecuniary in nature.

Finally, New York courts at the end of this era seemed to turn hostile toward sexual slander claims of all stripes, whether grounded initially in relational injury or emotional distress. Courts' antagonism toward plaintiffs' injuries was manifested in their great skepticism that the injuries the woman claimed-whatever their naturehad actually resulted from the offending statement. Judges frequently attributed emotional injury suffered to the female plaintiffs' extreme sensibilities and temperaments, suggesting that such emotional reactions were not a "natural consequence" of a defamatory statement. At the same time, legislatures in these states were getting closer to eliminating the issue altogether with an ostensibly "womanfriendly" turn: the recognition of sexual slander as a fourth category of slander per se.

Many gender-oriented observations might be offered with respect to this evolution of sexual slander doctrine in the nineteenth century. At first blush, one might conclude that any legal recognition of the injuries these female plaintiffs suffered, which made their slander claims actionable, was a positive turn of events for women. After all, in many of the earliest cases, courts were progressive in their recognition that injuries to 
these women's relationships-relationships of an essentially private or personal nature--were real injuries, sufficient to make a claim cognizable. Such recognition of relational injuries, outside the commercial and political sphere, was a rare turn in the law. Rather than recognizing the significance of the relationships themselves and their link to the plaintiff's dignity and standing in the community, however, courts validated these injuries as legally cognizable only by characterizing them as pecuniary. Courts, considering relational injuries that were intuitively noneconomic, recognized the injuries as worthy of redress only when they could be viewed as having economic consequences.

In addition to privileging injuries that could be viewed as economic or pecuniary, courts were dismissive of the foreseeability of emotional distress injuries in this context, as Chamallas has observed they were in others. Thus, some plaintiffs won sexual slander cases, but they did so only when courts could conceptualize their injuries in a way that reflected marketplace values, a fundamentally masculine conception. This was in contrast to recognizing or validating the injuries in the way the plaintiffs experienced them, as principally relational injuries or as injuries to wellbeing.

The sexual slander opinions from this era, then, may alternatively be seen as progressive and regressive. The "good news," so to speak, is that these courts at least implicitly recognized the value of human relationships, both social and intimate. This is no small matter given the law's typical preoccupation solely with the public sphere-the commercial and political marketplace and transactions and relations occurring in that sphere. The "bad news," on the other hand, is that courts acknowledged the relationships and recognized harm to them only when they could identify or-through sometimes contorted reasoning-label as pecuniary, an injury flowing from the damaged relationship.

If courts' recognition of women's injuries for sexual slander represents a mixed bag in terms of the gender politics reflected therein, what of the gender politics of the ultimate legislative and judicial recognition of sexual slander as a fourth slander per se category? At the most basic level, it seems appropriate to ask if the recognition of this woman-specific slander per se category was a "net gain" for women. On the one hand, the change in the law endowed women with the considerable practical benefit of not having to prove special damages in order to state an actionable claim. It alleviated the need to prove injuries of a sort that the law would find cognizable, and to avoid the moving target that such questions had become as courts over the decades altered the criteria for establishing pecuniary injury. In short, recognition of this fourth category made it easier for women to win their cases. However, this turn of events surely also had negative consequences as it meant that the law greatly reinforced the social significance attached to a woman's sexual purity. In the same way that slander law had recognized the significance to a businessman of a statement undermining his skill or expertise in his trade or business, the law of slander came explicitly and undeniably to recognize the primacy of a woman's sexual purity as a measure of her worth.

Looking critically at these legal developments, one might conclude that while they were facial victories for a few nineteenth-century female plaintiffs, women's long-term interests had ultimately been subverted by the law. Sexually slandered women, by seeking legal redress for their very personal, dignitary, and relational injuries, permitted-indeed, even encouraged-courts to recharacterize their injuries as property-type injuries. In addition, with the recognition of sexual slander for women as slander per se, the law gained an additional tool for monitoring and regulating 
women's sexuality. By seeking legal redress-and ultimately getting it with greater ease for statements charging them with "lewdness," adultery, fornication, or some other unacceptable sexual behavior-women were surely pawns in the law's reinforcement of the notion that their sexual purity was the sole valuable component of their "property" interests in their individual reputations. Indeed, these women may not have been achieving redress for themselves at all. In many cases, they were surely pawns in the their husbands', their fathers', and the legal system's commodification of their sexuality. Any benefit of this commodification redounded men, who were so often the real parties in interest with respect to that valuable commodity.

Nineteenth-century legal rules around sexual slander thus had unfortunate consequences for women, reinforcing the social significance of their sexual virtue whether they won or lost their cases, and clearly propertizing their virtue when they won. It is thus appropriate to ask what rules and results might have been preferable. What legal doctrines and rules would have been appropriate? One desirable outcome would have been to broaden the jurisdiction of the courts, with an accompanying broader array of remedies. For example, rather than requiring plaintiffs who sought redress for sexual slander to show some financial or economic consequence in exchange for being eligible for a damages award, courts might have accepted jurisdictions over these claims even absent pecuniary harm. Attendant to that expanded concept of what constitutes a legally cognizable claim for slander, courts might have expanded the array of remedies to which they had access. Courts might have followed the lead of English ecclesiastical courts, issuing declaratory judgments of sorts affirming or "reinstating" a woman's reputation for sexual propriety or virtue, or demanding an apology from the defendant. ${ }^{244}$

Interestingly, one early Alabama decision suggested this resolution, albeit in a circuitous way. The appellate court there overturned a jury verdict in favor of the sexually slandered plaintiff because she had failed to plead and prove the requisite special damages. In doing so, the court quipped:

It must be great gratification of the [plaintiffs], however, that they have really effected every thing which could be important to them, by the action. The cause has been submitted to a jury, and a verdict returned for five hundred dollars damages-thus manifesting the purity of Mrs. Carter's character; and fixing the offence of moral, although not legal slander upon the [defendant]. ${ }^{245}$

Thus, although the plaintiff could recover no monetary award, the court made clear its view that she had "won" that which mattered most: a jury's declaration of her sexual virtue and the corresponding conclusion of the slanderer's moral wrong.

Indeed, nineteenth-century courts might have taken a tack associated with modern defamation reform: they might have encouraged or ordered a defendant to retract his or her statement or to apologize, in lieu of a monetary award. ${ }^{246}$ Alternatively, they might

244. See supra notes 60-62 and accompanying text (discussing the remedies available to ecclesiastical courts).

245. Berry v. Carter, 4 Stew. \& P. 387 (Ala. 1833).

246. The commentary on libel reform, including provisions regarding retraction and correction, has been extensive in the past two decades. See, e.g., Proposal for the Reform of Libel Law, Report of the Libel Reform Project of the Annenberg Washington Program at 10 (1988) (proposal for libel reform that would mandate that plaintiff request a reply or retraction 
have issued declaratory judgments on the truth or falsity of the offending statement, another idea associated with contemporary defamation reform. ${ }^{247}$ Providing such remedies would have avoided the necessity of articulating the woman's injury as one cognizable in the marketplace, and therefore of commodifying her virtue. While recognizing and administering these alternative remedies would not have thwarted the law's reinforcement of the significance of female sexual virtue, doing so would have had the benefit of acknowledging the dignitary nature of the injury, as well as recognizing the value of the plaintiffs' relationships for what they were.

before suing; permit transformation of damages action into action for declaratory judgment); David A. Anderson, Is Libel Law Worth Reforming?, 140 U. PA. L. REv. 487 (1991); James H. Hulme, Vindicating Reputation: An Alternative to Damages as a Remedy for Defamation, 30 AM. U. L. REV. 375 (1981); Rodney A. Smolla, Taking Libel Reform Seriously, 38 MERCER L. REV. 793 (1987).

In California, for example, a plaintiff may recover only "special damages" in an action for defamation unless the plaintiff demands and is refused a correction. CAL. CIv. CODE $\S 48 a(1)$ (West 2003). The plaintiff must demand the correction within 20 days of learning of the publication or broadcast of the offending statement. Id. The defendant must publish the correction in "substantially as conspicuous a manner" as the statements complained in the complaint to be libelous. Id. $\S 48 \mathrm{a}(2)$. "Special damages" are defined as "all damages which plaintiff alleges and proves that he has suffered in respect to his property, business, trade, profession or occupation, including such amounts of money as the plaintiff alleges and proves he has expended as a result of the alleged libel, and no other." $l d$. $\$ 48 \mathrm{a}(4)(\mathrm{b})$.

247. See, e.g., David A. Barrett, Declaratory Judgments for Libel: A Better Alternative, 74 CAL. L. REv. 847 (1986); Marc A. Franklin, A Declaratory Judgment Alternative to Current Libel Law, 74 CAL. L. Rev. 809 (1986); Pierre N. Leval, The No-Money, No-Fault Libel Suit: Keeping Sullivan in Its Proper Place, 101 HaRv. L. REv. 1287 (1988). 